\title{
Immigrant-native differences in long-term self-employment
}

\author{
Lina Aldén • Spencer Bastani (i) . \\ Mats Hammarstedt • Chizheng Miao
}

Accepted: 29 January 2021 / Published online: 9 July 2021

(C) The Author(s) 2021

\begin{abstract}
We study immigrant-native differences in long-term self-employment in Sweden combining population-wide register data and a unique survey targeting a large representative sample of the total population of long-term self-employment. Using the registers, we analyze the evolution of labor and capital incomes during the first 10 years following selfemployment entry. We find that immigrant-native differences in labor income become smaller, whereas immigrant-native differences in capital income grow stronger, over the course of self-employment. These findings are robust to controlling for factors such as organizational form and type of industry. We use the survey data to gain further insights into immigrant-
\end{abstract}

\section{Aldén}

Department of Economics and Statistics, Linnaeus

University, Växjö, Sweden

e-mail: lina.alden@lnu.se

S. Bastani $(\square)$

Institute for Evaluation of Labour Market and Education Policy (IFAU), Uppsala, Sweden and Research Institute of Industrial Economics (IFN), Stockholm, Sweden

e-mail: spencer.bastani@ifau.uu.se

\section{Hammarstedt}

Department of Economics and Statistics, Linnaeus University, Växjö, Sweden and Research Institute of Industrial Economics (IFN), Stockholm, Sweden e-mail: mats.hammarstedt@lnu.se

C. Miao

Department of Economics and Statistics, Linnaeus

University, Växjö, Sweden

e-mail: chizheng.miao@lnu.se native differences among the long-term self-employed, and show that immigrant self-employed experience more problems and earn less, but work harder than native self-employed. They also have a less personal relation to their customers, do not enjoy their work as much as natives, and appear to have different perspectives on self-employment in general.

Keywords Self-employment · Immigration ·

Integration $\cdot$ Long-term $\cdot$ Survey

JEL Classifications J15 $\cdot$ J24 $\cdot$ L26 $\cdot$ D31

\section{Introduction}

Research regarding immigrant-native differences in self-employment rates has been conducted in several OECD counties. ${ }^{1}$ Besides mapping immigrant-native differences in self-employment rates, much attention has been paid to identify the determinants behind the self-employment entry decision among different

\footnotetext{
${ }^{1}$ Studies have been conducted in the USA (see, e.g., Borjas (1986), Yuengert (1995), Fairlie and Meyer (1996), Fairlie (1999), Hout and Rosen (2000), Fairlie and Robb (2007b) and Robb and Fairlie (2009)) and in Australia (see Le (2000)), as well as in different European countries (see e.g., Clark and Drinkwater (2000) and Clark et al. (2017) for studies from the UK, Constant and Zimmermann (2006) for a study from Germany, and Hammarstedt (2001) for a study of Sweden).
} 
groups of immigrants. Studies from different countries have shown that factors such as family traditions, home-country traditions, and the existence of ethnic enclaves, as well as discrimination in the wage-employment sector, are important determinants behind the self-employment entry decision among certain immigrant groups. ${ }^{2}$ However, despite the relatively large amount of research that has focused on immigrant-native differences in self-employment, and despite the fact that certain immigrant groups have higher exit rates from self-employment, less is known about the extent to which there are immigrantnative differences among individuals who remain selfemployed over the years, i.e., if there are immigrantnative differences in long-term self-employment.

In this paper, we aim to fill this knowledge gap by conducting a study in which we compare different economic outcomes for foreign- and native-born individuals who have been self-employed for a spell of 10 years or more in Sweden. Since the share of self-employed immigrants has increased in several countries over the years, and since self-employment often has been viewed as a way for immigrants who have problems in entering the labor market to escape poverty and unemployment, it is important to increase our understanding of how self-employed immigrants perform in the long run. Sweden is a suitable country for a study of long-term outcomes of self-employed immigrants since it is a country with a relatively long history of immigration and a country that also has experienced a large increase in self-employment among foreign-born individuals during the past 30 years.

Our study is conducted with the help of a combination of high-quality Swedish register data and a unique survey designed specifically for this paper. From the register data, we obtain information about demographic background factors such as age, educational attainment, and the family situation of individuals. We also obtain information about labor and capital income. The survey, which targeted foreignborn individuals as well as native-born Swedes with

\footnotetext{
$\overline{{ }^{2} \text { Determinants }}$ behind the self-employment decision among immigrants in different countries have been analyzed by Borjas (1986), Yuengert (1995), Fairlie and Meyer (1996), Clark and Drinkwater (2000), Clark and Drinkwater (2002), Hammarstedt and Shukur (2009), and Andersson and Hammarstedt (2015).
}

long-term experience from self-employment, allows us to obtain answers to questions that cannot be addressed using register data. The questions in the survey depart from results and experiences from previous research regarding immigrant self-employment, and aim to further increase our understanding regarding the success factors and obstacles self-employed immigrants encounter in their businesses. By combining register and survey data, we are able to paint a detailed picture of the background factors that characterize long-term self-employed natives and immigrants, as well as analyze what factors these individuals themselves consider to be the most important for their self-employment experience.

Throughout the paper, we define immigrants as foreign-born individuals. We further divide the foreign-born population by region of birth, separating between European and non-European immigrants. This is due to the fact that research has shown that non-European immigrants, more often than European immigrants, suffer from low earnings and high rates of unemployment and are over-represented in the selfemployment sector. ${ }^{3}$

We arrive at several interesting results. Our register analysis shows that, over the course of the first decade of self-employment experience, immigrantnative differences in labor income become smaller over time, whereas immigrant-native differences in capital income grow stronger. These findings are robust to controlling for factors such as organizational form and type of industry. The survey results show that self-employed immigrants experience more problems and earn less, but work harder. They also have a less personal relation to their customers, do not enjoy their work as much as natives, and appear to have different perspectives on self-employment in general.

The remainder of the paper is organized as follows. In Section 2 below, we provide a brief discussion of Swedish immigration history and the composition of migration to Sweden during the last decades. Section 3 describes the register and survey data that we use in our analysis. In Section 4, we present an analysis of immigrant-native differences in long-term self-employment outcomes based on Swedish population registers, using a combination of graphical and

\footnotetext{
${ }^{3}$ This is true not only for Sweden (see, e.g., Ek et al. 2020 and Aldén \& Hammarstedt 2017) but also for several European countries (see, e.g., OECD 2017).
} 
regression analyses. In Section 5, we analyze our survey targeted at the long-term self-employed which allows us to obtain insights into the factors explaining the outcome differences documented in Section 4. Finally, Section 6 offers concluding remarks.

\section{Immigration to Sweden}

Sweden has experienced a relatively extensive immigration during the decades after World War II. However, the characteristics of this immigration have changed over time. ${ }^{4}$ During the end of the 1940s, immigration to Sweden consisted primarily of refugees from Eastern Europe. In the 1950s, labor force migration reached significant proportions as a result of the industrial and economic expansion. The labor force migration peaked during the 1950s and 1960s, with the influx of immigrants coming predominantly from Sweden's neighbors (e.g., Finland) and from countries in Western and Southern Europe (e.g., Italy, Greece, West Germany, Yugoslavia).

From the 1970s and onwards, immigration to Sweden has consisted primarily of refugee immigrants and "tied movers" or relatives of already admitted immigrants. In the 1970s, refugee migration from Latin America increased, while during the 1980s, many refugees came from Africa and the Middle East.

Migration from Europe increased temporarily again during the early 1990s. This involved refugees fleeing the civil war in former Yugoslavia. Since the mid1990s, most of the immigrants to Sweden have been refugees from countries in and around the Middle East and Africa. During the 2000s, immigration to Sweden reached historically high numbers, peaking during the years 2015 and 2016 with a large influx of refugees from Syria, Iraq, and also other countries in the Middle East and Africa.

As of 2020 , about $20 \%$ of Sweden's total population is foreign-born. The change from labor force migration to refugee migration has transformed the composition of the country's immigrant population. During recent decades, the share of immigrants born outside Europe has grown markedly, and today, around $55 \%$ of the foreign-born population originates

\footnotetext{
${ }^{4}$ The interested reader is referred to Boguslaw (2012) who presents a detailed description and discussion of Sweden's immigration history.
}

from countries outside Europe, with Syria, Iraq, Iran, and Somalia being the dominant countries. ${ }^{5}$

\section{Data and institutional setting}

\subsection{Register data}

The register data that we use in the paper consist of Swedish linked employer-employee data combined with administrative data from the Swedish tax authority. The data cover the period 2002 to 2016 and is longitudinal, enabling us to follow individuals over time. The data include information on sector of employment, labor, and capital income, as well as socio-economic and demographic information, such as educational attainment and immigration status. ${ }^{6}$

Throughout the paper, we define natives as those born in Sweden and immigrants as those who are born outside of Sweden. Hence, in our paper, immigrants correspond to first-generation immigrants. Using information on birth region, we further classify immigrants into European and non-European immigrants. The motivation behind this classification is that previous research has shown that non-European immigrants typically are considered to have a disadvantage in the Swedish labor market and are over-represented in the self-employment sector. These patterns are not unique to Sweden, and can be found in many other European countries. ${ }^{7}$

We define a person as self-employed if his/her main source of income are self-employment activities. ${ }^{8}$ To analyze long-term self-employment outcomes, our register analysis focuses on self-employment spells that began between 2002 and 2006. ${ }^{9}$ This allows us to

\footnotetext{
${ }^{5}$ Detailed information about the ethnic composition of the Swedish population can be found at Statistics Sweden, www. scb.se.

${ }^{6}$ The variable educational attainment measures the highest obtained education. For foreign-born individuals with education acquired abroad, the variable is based on self-reported information.

${ }^{7}$ In many European countries, non-European immigrants have a higher rate of self-employment than natives, such as in the UK, Finland, Belgium, and Hungary (OECD, 2017).

${ }^{8}$ The measurement of sector of employment is made in November each year, and the definition of self-employment used in the paper corresponds to the definition used by Statistics Sweden.

${ }^{9}$ We define an entry into self-employment if an individual was not self-employed in the previous year.
} 
Fig. 1 Share who remain in self-employment. Fraction of people who remain self-employed for at least $T$ years after having entered self-employment sometime between 2002 and 2006 (referred to as $T=0$ )

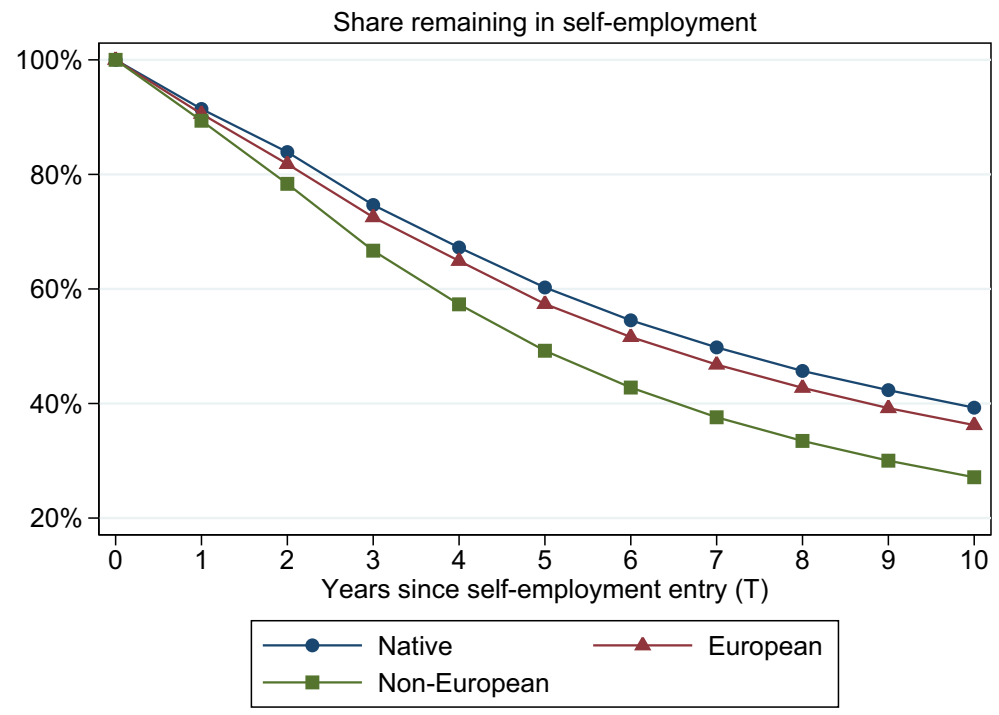

follow individuals for at least 10 years. In principle, we could include earlier self-employment experiences into our analysis, but we choose the relatively narrow interval 2002-2006 in order to focus on businesses that develop during roughly the same point in time and hence face roughly the same business climate and macroeconomic conditions. Furthermore, this ensures that the sample used in the analysis based on register data matches the survey data. The data allow us to distinguish between incorporated and unincorporated business owners, as well as to identify people who are wage-employed. In our analysis, we restrict our attention to individuals aged 20 to 64 and exclude self-employed individuals in the agricultural sector.

To compare self-employment performance between immigrants and natives, we focus on annual taxable labor and capital income from the tax administration. These are the two main sources of economic compensation to individuals and are tightly connected to individual well-being. Labor income represents the sum of the employment income from wage and business activities, minus a general deduction. The capital income variable includes interest income from savings, and dividend income from stocks and ownership in closely held corporations. ${ }^{10}$

Figure 1 shows the fraction of people in our sample who stay self-employed for at least $T$ years, where $T=0, \ldots, 10$ and $T=0$ corresponds to the year of self-employment entry. From the figure,

\footnotetext{
${ }^{10}$ Table 17 provides a detailed description of all variables.
}

we observe that the share who remain in selfemployment is higher among natives than among European and non-European immigrants. Ten years after self-employment entry, around $40 \%$ of natives are still self-employed, whereas for European immigrants, the corresponding share is somewhat lower. Among non-European immigrants, on the other hand, the corresponding share is $30 \% .^{11}$

Our focus is on immigrant-native differences in long-term self-employment. We therefore focus on individuals who became self-employed in 2002-2006 and remained in self-employment for at least ten consecutive years. These individuals are defined as long-term self-employed in our paper and correspond to those who are still in the sample at $T=10$ in Fig. 1. In total, the sample includes 54,486, 4089, and 3095 self-employed natives, European immigrants, and non-European immigrants, respectively.

Our register-based analysis will be divided into two parts. We will first graphically analyze how taxable labor and capital income evolve over the first 10 years following self-employment entry. We will then estimate, in a regression framework, the effect of immigrant background on these outcome measures, averaged over these 10 years. The purpose of analyzing the effect of immigrant background on these ten year averages is to approximate "permanent" income measures for the long-term self-employed.

\footnotetext{
${ }^{11}$ Notice that entrepreneurial exit is not equal to failure, as discussed by DeTienne (2010).
} 
Table 1 below shows summary statistics for our final sample. ${ }^{12}$ The first thing to notice is that, on average, self-employed natives have both higher labor and capital income than self-employed European and nonEuropean immigrants. In terms of individual characteristics at the year of self-employment entry, we find that on average, European immigrants are older, and non-European immigrants are younger than their native counterparts. For all groups, the majority of the self-employed are male, with the fraction being the largest among non-European immigrants and smallest among European immigrants. Non-European immigrants are on average the least educated and European immigrants are the most educated. In addition, as compared to natives and European immigrants, nonEuropean immigrants are more likely to be married and more likely to have children under the age of 18 living at home.

In terms of business characteristics, around half of native self-employed individuals start an incorporated business, whereas only around $14 \%$ of self-employed non-European immigrants do so. ${ }^{13}$ Furthermore, we find that about $44 \%$ of non-European immigrants start businesses in industries with low barriers to entry while the corresponding share among natives and European immigrants is only around $20 \% .^{14}$

\subsection{Survey data}

A key aspect of our contribution is that we combine a register analysis for the total population, with the

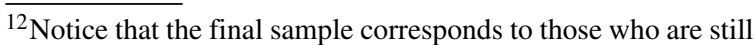
in our sample at $T=10$. In Appendix Table 15, we show the average characteristics of all individuals who started a business between 2002 and 2006, and the patterns look similar.

${ }^{13}$ Levine and Rubinstein (2017) show that incorporated business owners in the USA tend to be both more educated and have stronger non-routine cognitive abilities than unincorporated business owners. Furthermore, their results suggest that the choice of corporate form mostly reflects the ex ante nature of the business, not the ex post performance. In addition, previous literature has shown that, due to tax incentives, high-income people are more likely to incorporate their business relative to low-income earners in Sweden (Edmark and Gordon, 2013). We present summary statistics separately for corporate and non-corporate business owners in Table 10 in the Appendix.

${ }^{14}$ Our classification follows Lofstrom and Bates (2013) who identify industries with low barriers to entry using Swedish industry codes at a 2-digit level. The industries with low barriers to entry are mainly composed of personal services (excluding professional business services), transportation, and retail.
}

results from a tailor-made, register-linked survey that enables us to learn about the factors that native and immigrant entrepreneurs themselves consider to be important for their long-term self-employment experience.

The survey was designed uniquely for this paper and was conducted in collaboration with Statistics Sweden between September 2018 and January 2019. It targeted a random sample of the total population of self-employed in Sweden who had been selfemployed for ten consecutive years between 2007 and 2016 (we exclude the self-employed in the agricultural sector). ${ }^{15}$ A total of around 17,500 survey questionnaires were sent out by regular mail and the response rate was around $40 \%$, corresponding to around 7000 respondents. Among the respondents, the shares of natives, and European and non-European immigrants were about 41,34 , and $25 \%$, respectively. ${ }^{16}$

We selected the survey questions based on results from previous research regarding self-employment and immigrant self-employment. ${ }^{17}$ To understand the nature of the businesses of the self-employed in our sample, we asked different questions about their self-employment experience, and the characteristics of their firms. It is well known that social and entrepreneurial networks, educational attainment, and access to financial capital are of central importance for the possibility to become and succeed as

\footnotetext{
15 Notice that our register analysis and survey analysis are based on slightly different samples. The survey targeted all individuals who were self employed for 10 consecutive years between 2007 and 2016, whereas the register sample focuses on all those who started a business between 2002 and 2006 and who were then self-employed for at least ten consecutive years. The reason for this discrepancy is that we wish to have as large of a sample as possible when conducting the register analysis to allow to investigate subgroup differences.

${ }^{16}$ The survey sample was stratified based on gender and region of birth (Sweden, Europe, the Middle East, and other nonEuropean countries). In total, eight strata $(2 \times 4)$ were created and a random sample of 3000 individuals was drawn for each strata. For the strata of men and women born in the Middle East and other non-European countries, the population size was smaller than 3000 . Hence, in these cases, the survey targeted the total population. In the analysis, we have merged the Middle East and other non-European countries into one category.

${ }^{17}$ In addition, we gathered feedback on the survey from Almi Kronoberg, a local chapter of a state-owned organization that offers financing and support to native and immigrant entrepreneurs in Sweden.
} 
Table 1 Summary statistics for the sample used in the register analysis

\begin{tabular}{|c|c|c|c|c|c|}
\hline & $\begin{array}{l}\text { (1) } \\
\text { Native }\end{array}$ & $\begin{array}{l}(2) \\
\text { European }\end{array}$ & $\begin{array}{l}\text { (3) } \\
\text { Non-European }\end{array}$ & $\begin{array}{l}(4) \\
(1)-(2)\end{array}$ & $\begin{array}{l}(5) \\
(1)-(3)\end{array}$ \\
\hline \multicolumn{6}{|c|}{ Outcome variables (averages in SEK): } \\
\hline Labor income & $\begin{array}{l}333,000 \\
(211,000)\end{array}$ & $\begin{array}{l}282,000 \\
(196,000)\end{array}$ & $\begin{array}{l}216,000 \\
(143,000)\end{array}$ & $51,000 * * *$ & $117,000 * * *$ \\
\hline Capital income & $\begin{array}{l}68,600 \\
(674,000)\end{array}$ & $\begin{array}{l}60,200 \\
(1,491,000)\end{array}$ & $\begin{array}{l}16,600 \\
(120,000)\end{array}$ & 8400 & $52,000 * * *$ \\
\hline \multicolumn{6}{|c|}{ Characteristics at the year of self-employment entry: } \\
\hline Age & $\begin{array}{l}40.4 \\
(8.339)\end{array}$ & $\begin{array}{l}42.2 \\
(7.675)\end{array}$ & $\begin{array}{l}38.7 \\
(7.992)\end{array}$ & $-1.8 * * *$ & $1.7 * * *$ \\
\hline Male & $\begin{array}{l}0.730 \\
(0.444)\end{array}$ & $\begin{array}{l}0.653 \\
(0.476)\end{array}$ & $\begin{array}{l}0.801 \\
(0.399)\end{array}$ & $0.077 * * *$ & $-0.071 * * *$ \\
\hline Primary school & $\begin{array}{l}0.142 \\
(0.349)\end{array}$ & $\begin{array}{l}0.139 \\
(0.346)\end{array}$ & $\begin{array}{l}0.284 \\
(0.451)\end{array}$ & 0.003 & $-0.142 * * *$ \\
\hline High school & $\begin{array}{l}0.555 \\
(0.497)\end{array}$ & $\begin{array}{l}0.463 \\
(0.499)\end{array}$ & $\begin{array}{l}0.436 \\
(0.496)\end{array}$ & $0.092 * * *$ & $0.119 * * *$ \\
\hline College & $\begin{array}{l}0.303 \\
(0.459)\end{array}$ & $\begin{array}{l}0.398 \\
(0.490)\end{array}$ & $\begin{array}{l}0.280 \\
(0.449)\end{array}$ & $-0.095^{* * *}$ & $0.023 * * *$ \\
\hline Marital status & $\begin{array}{l}0.471 \\
(0.499)\end{array}$ & $\begin{array}{l}0.598 \\
(0.490)\end{array}$ & $\begin{array}{l}0.708 \\
(0.455)\end{array}$ & $-0.127 * * *$ & $-0.237 * * *$ \\
\hline Children in household & $\begin{array}{l}1.01 \\
(1.087)\end{array}$ & $\begin{array}{l}0.98 \\
(1.071)\end{array}$ & $\begin{array}{l}1.43 \\
(1.270)\end{array}$ & $0.03^{*}$ & $-0.42 * * *$ \\
\hline Incorporated business & $\begin{array}{l}0.519 \\
(0.500)\end{array}$ & $\begin{array}{l}0.348 \\
(0.476)\end{array}$ & $\begin{array}{l}0.136 \\
(0.343)\end{array}$ & $0.171 * * *$ & $0.383 * * *$ \\
\hline Low barrier industry & $\begin{array}{l}0.179 \\
(0.383)\end{array}$ & $\begin{array}{l}0.220 \\
(0.415)\end{array}$ & $\begin{array}{l}0.434 \\
(0.496)\end{array}$ & $-0.041 * * *$ & $-0.255^{* * *}$ \\
\hline$N$ & 54,486 & 4089 & 3095 & & \\
\hline
\end{tabular}

The table contains averages with standard deviations in parentheses. *, **, and *** denote statistical significance at the 10,5 , and 1 percent level, respectively. Columns (4) and (5) refer to pair-wise $t$ tests for testing statistically significant differences

self-employed, and that the importance of these factors may vary between immigrants and natives (see, for example, Blanchflower \& Oswald 1998; Blanchard et al. 2008). We therefore asked the respondents how important they perceived that these factors have been for their self-employment activities. Furthermore, it is well known that immigrants may encounter other problems than natives in their firms (see, for example, Constant \& Zimmermann 2006; Aldén \& Hammarstedt 2016). We therefore asked the respondents about perceived success factors and perceived obstacles in their self-employment activities. Table 18 in Appendix B presents the full set of survey questions.
To assess the representativeness of our survey data, Table 2 presents descriptive statistics where we compare the survey respondents and the population data from which the survey was drawn. ${ }^{18}$ The table shows that the survey sample and the corresponding population data from which the survey was sampled are overall quite similar in terms of average characteristics. The only clear exceptions are that non-European immigrants in the survey data are more likely to be college educated than non-European immigrants in the

\footnotetext{
${ }^{18} \mathrm{We}$ also compare the survey respondents and non-respondents in Appendix Table 11.
} 
Table 2 Comparison of survey respondents and the survey population data

\begin{tabular}{|c|c|c|c|c|c|c|}
\hline & (1) & (2) & (3) & (4) & (5) & (6) \\
\hline & \multicolumn{3}{|c|}{ Respondents } & \multicolumn{3}{|c|}{ Survey population data } \\
\hline & Native & European & Non-European & Native & European & Non-European \\
\hline \multirow[t]{2}{*}{ Age } & 56.9 & 57.7 & 54.2 & 59.1 & 59.7 & 52.4 \\
\hline & $(9.0)$ & $(8.7)$ & $(8.2)$ & $(12.0)$ & $(11.1)$ & $(9.2)$ \\
\hline \multirow[t]{2}{*}{ Female } & 0.280 & 0.320 & 0.272 & 0.297 & 0.356 & 0.183 \\
\hline & $(0.449)$ & $(0.467)$ & $(0.445)$ & $(0.457)$ & $(0.479)$ & $(0.386)$ \\
\hline \multirow[t]{2}{*}{ Primary school } & 0.169 & 0.171 & 0.162 & 0.215 & 0.168 & 0.288 \\
\hline & $(0.374)$ & $(0.377)$ & $(0.369)$ & $(0.411)$ & $(0.374)$ & $(0.453)$ \\
\hline \multirow[t]{2}{*}{ High school } & 0.516 & 0.420 & 0.436 & 0.514 & 0.465 & 0.446 \\
\hline & $(0.500)$ & $(0.494)$ & $(0.496)$ & $(0.500)$ & $(0.499)$ & $(0.497)$ \\
\hline \multirow[t]{2}{*}{ College } & 0.315 & 0.409 & 0.402 & 0.271 & 0.366 & 0.266 \\
\hline & $(0.465)$ & $(0.492)$ & $(0.491)$ & $(0.444)$ & $(0.482)$ & $(0.442)$ \\
\hline \multirow[t]{2}{*}{ Marital status } & 0.638 & 0.683 & 0.721 & 0.600 & 0.630 & 0.748 \\
\hline & $(0.481)$ & $(0.466)$ & $(0.449)$ & $(0.490)$ & $(0.483)$ & $(0.434)$ \\
\hline \multirow[t]{2}{*}{ Children in household } & 0.394 & 0.401 & 0.710 & 0.380 & 0.330 & 0.903 \\
\hline & $(0.781)$ & $(0.846)$ & $(1.037)$ & $(0.799)$ & $(0.761)$ & $(1.171)$ \\
\hline \multirow[t]{2}{*}{ Incorporated business } & 0.538 & 0.362 & 0.219 & 0.432 & 0.304 & 0.200 \\
\hline & $(0.499)$ & $(0.481)$ & $(0.414)$ & $(0.495)$ & $(0.460)$ & $(0.400)$ \\
\hline \multirow[t]{2}{*}{ Low barrier industry } & 0.201 & 0.210 & 0.454 & 0.202 & 0.209 & 0.437 \\
\hline & $(0.401)$ & $(0.407)$ & $(0.498)$ & $(0.402)$ & $(0.406)$ & $(0.496)$ \\
\hline \multirow[t]{2}{*}{ Average disposable income $\dagger$} & 365,000 & 299,000 & 245,000 & 336,000 & 300,000 & 230,000 \\
\hline & $(539,000)$ & $(294,000)$ & $(281,000)$ & $(546,000)$ & $(1,638,000)$ & $(198,000)$ \\
\hline$N$ & 2843 & 2418 & 1765 & 130,924 & 10,385 & 5883 \\
\hline
\end{tabular}

Mean coefficients; standard deviation in parentheses. All summary statistics are computed from population registers in 2016, which is the most recent year we can match with our survey data. In the right panel, we write "Survey population data" to distinguish it from the register data used in Section 4, which covers a slightly different time period. The summary statistics for respondents are weighted using the survey weights. $\dagger$ Average disposable income between 2007 and 2016

population data (40\% versus $26 \%$ ) and are also more likely to be female (27\% versus $18 \%) .{ }^{19}$

Comparing the characteristics of natives and immigrants within the group of survey respondents, we find that the share of women is about $30 \%$ for both natives and immigrants. The average age in the year 2016 is about 56, 57, and 54 for natives, and European and non-European immigrants, respectively. Among the survey respondents, both natives and immigrants seem to have similar education levels. Non-European

\footnotetext{
${ }^{19}$ Notice that the register data described in Section 3.1, and the population data described for reference purposes in Table 2 are not the same, as they cover slightly different time periods. For this reason, the label referring to columns (4)-(5) in Table 2 is "Survey population data" to distinguish it from the population data used in the register analysis.
}

immigrants are more likely to be married and more likely to have children under the age of 18 at home than the other groups. Furthermore, among selfemployed non-European immigrants, the share of individuals with an incorporated business is much smaller and the share of individuals working in industries with low barriers to entry is much higher, relative to natives and European immigrants. In terms of income, we find that self-employed natives have on average a much higher disposable income than both European and non-European immigrants. ${ }^{20}$

\footnotetext{
${ }^{20}$ When analyzing the survey data, we use disposable income as a proxy for the sum of labor and capital income since Statistics Sweden did not provide us with taxable labor and capital income data in the set of register variables connected to the survey data set.
} 


\section{Economic outcomes for the long-term self-employed: evidence from Swedish registers}

\subsection{Graphical evidence}

We begin with a graphical analysis where we, for different immigrant groups, explore how measures of self-employment performance evolve during the first 10 years following self-employment entry.

In Fig. 2, we analyze the evolution of labor income, focusing on yearly population averages as well as the 25th, 50th, and 75th percentiles. Similar to Fig. 1, $T=$ 0 corresponds to the year of self-employment entry (which is potentially different for each individual).

The figure shows that there is a sizable gap between natives and immigrants, especially in the case of nonEuropean immigrants. The gap decreases with selfemployment experience, but a noticeable difference is evident even after 10 years in self-employment. The fact that all the graphs are upwards sloping likely reflects the fact that many businesses grow over time, and therefore generate an increasing stream of income to their owners. We can also see that the gap between natives and immigrants diminishes over time. As time goes by, immigrants become more and more integrated into society (e.g., by learning language skills) and are therefore able to achieve business incomes that are more similar to those of natives.

Figure 3 shows the trajectories for capital income. The figure in the left panel shows capital income trajectories in a graph similar to the first panel of Fig. 2. The perhaps most interesting observation is that, in contrast to the evolution of labor income, we find that the gap in terms of capital income between self-employed natives and non-European immigrants, widens over time. Thus, when it comes to capital income, non-European immigrants do not seem to catch up in the same way as in Fig. 2. The gap between natives and European immigrants is on the other hand quite small, at least when looking at average outcomes. Since a sizable share of individuals earn zero capital income, the right panel of Fig. 3 shows the share of positive (non-zero) capital income among natives and immigrants. The figure shows that the share of individuals with positive capital income increases for both natives and immigrants over the
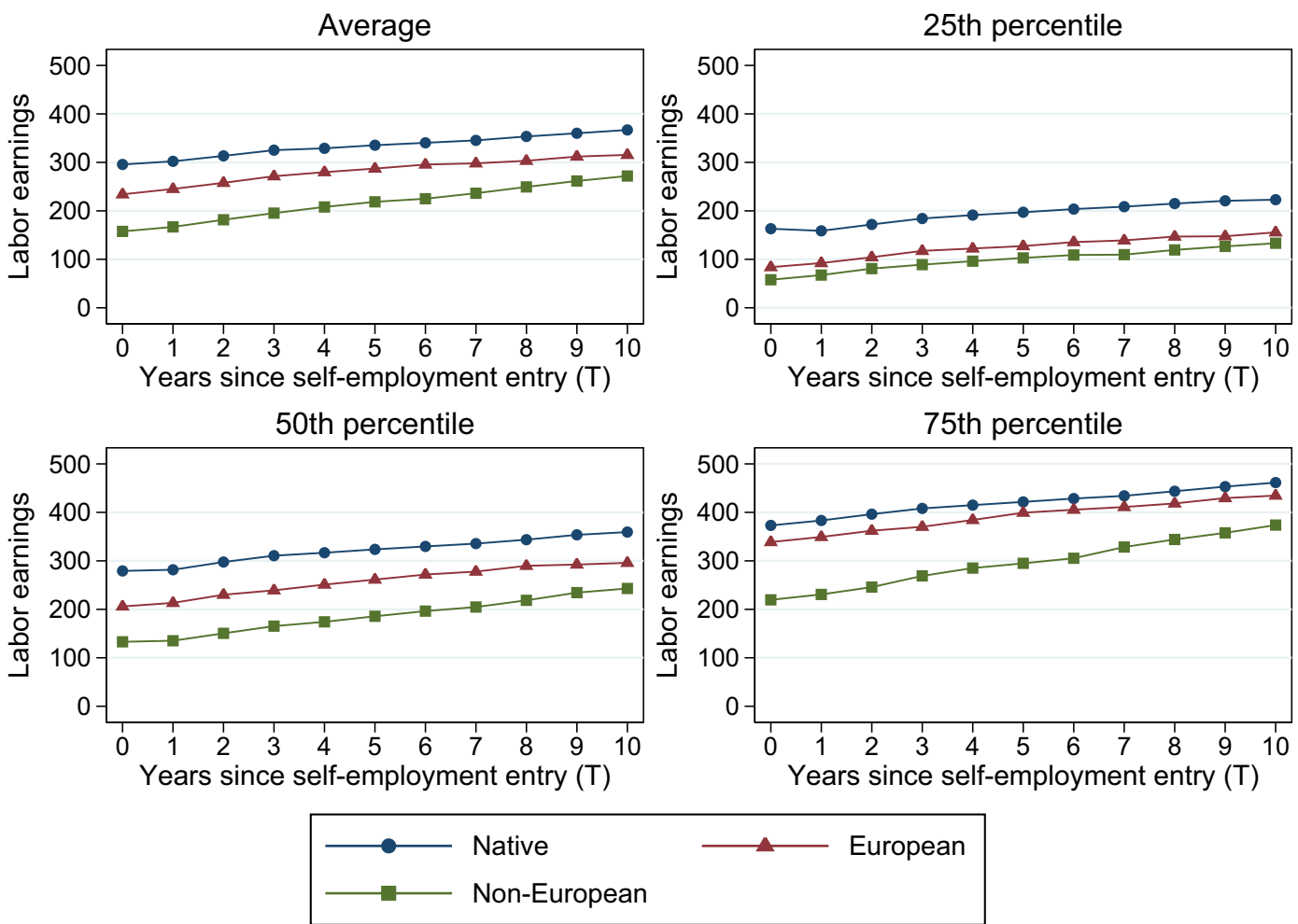

Fig. 2 Labor income. All outcomes measured in thousands of SEK 
Fig. 3 Capital income. All outcomes measured in thousands of SEK
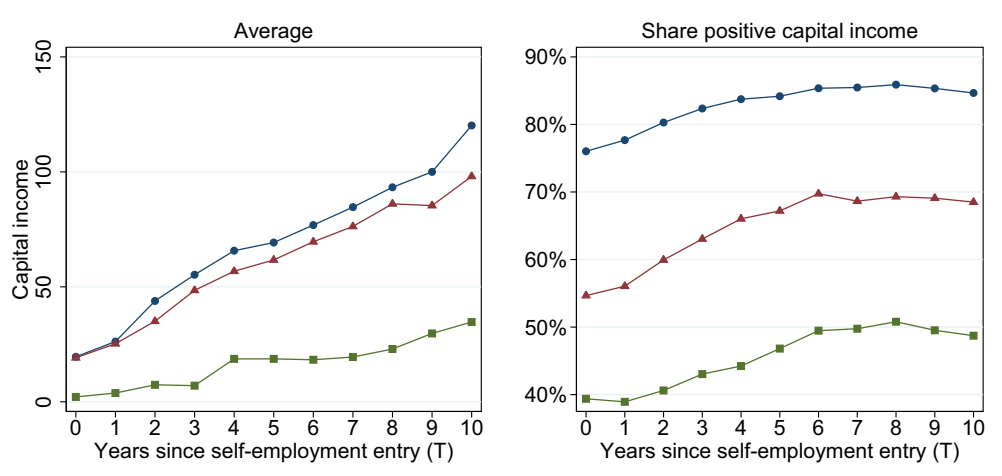

$$
\begin{aligned}
& \longrightarrow \text { Native } \\
& \longrightarrow \text { Non-European }
\end{aligned}
$$

course of self-employment. However, even after a long time in self-employment, e.g., at $T=10$, less than $50 \%$ of non-European immigrants earn a positive capital income.

In Fig. 4, we analyze the evolution of the distribution of capital income among the self-employed with positive capital income by inspecting the evolution of different percentiles. We observe a clear, widening gap between natives and immigrants in the top quartile of the distribution, in particular between natives and non-European immigrants.

In the analysis so far, we have not considered that natives and immigrants run different types of firms with respect to corporate form and type of industry. Figure 5 therefore shows the share of self-employed who have an incorporated business (left panel) and the share who work in industries with low barriers to entry (right panel), and how these variables evolve over time. We see that the fraction of non-European immigrants who have an incorporated business is very low. The share at $T=0$ is about $15 \%$ among non-European immigrants, while the corresponding shares for natives and European immigrants are about $35 \%$ and $50 \%$, respectively. However, the extent of incorporation increases over time in all immigrant groups, but there is no pattern of convergence or divergence across immigrant groups. ${ }^{21}$ About half of

\footnotetext{
${ }^{21}$ In 2010 , there was a reform that lowered the minimum financial capital required to start an incorporated business from 100,000 SEK to 50,000 SEK. Given that in our sample, all individuals started their business in 2002-2006, the reform might have induced some people to switch to an incorporated business 4-8 years after self-employment entry. We see a small tendency for the extent of incorporation to be somewhat higher among non-European immigrants (who are more likely to be capital constrained) during these years.
}

non-European immigrants work in industries with low barriers to entry, whereas the share is only about $20 \%$ for natives and European immigrants. Furthermore, it does not seem that long-term entrepreneurs change industries during the first 10 years following self-employment entry. There is a small tendency for European immigrants to leave industries with low barriers of entry, but, overall, the likelihood of moving between low- and high-entry barrier industries is low for both natives and immigrants during the first 10 years.

In Appendix A, motivated by the immigrant-native differences documented in Fig. 5, we re-do Figs. 2 and 4 based on whether an individual starts an incorporated business or not at the time of self-employment entry (see Appendix Figs. 6, 7, 8, 9, 10, 11) and based on whether an individual starts a firm in a low barrierto-entry industry or not (see Appendix Figs. 12, 13, $14,15,16,17)$. These results show that capital income is generally much higher among those who start an incorporated business and those who start a business in an industry that does not classify as an industry with low barriers to entry. However, independently of the corporate form and type of industry at the time of self-employment entry, the immigrant-native gap in labor income seems to converge over time, whereas the immigrant-native gap in capital income seems to widen over time. ${ }^{22}$

One reason for the stronger growth of capital income among natives could be that natives run businesses that are more likely to generate capital income

\footnotetext{
${ }^{22}$ The only exception is the case of European immigrants, where we find that the labor income trajectories at the 50th and 75th percentiles are almost identical to those of natives for self-employed with incorporated firms (see appendix Fig. 6).
} 
Fig. 4 Evolution of capital income, conditional on positive capital income. All outcomes measured in thousands of SEK
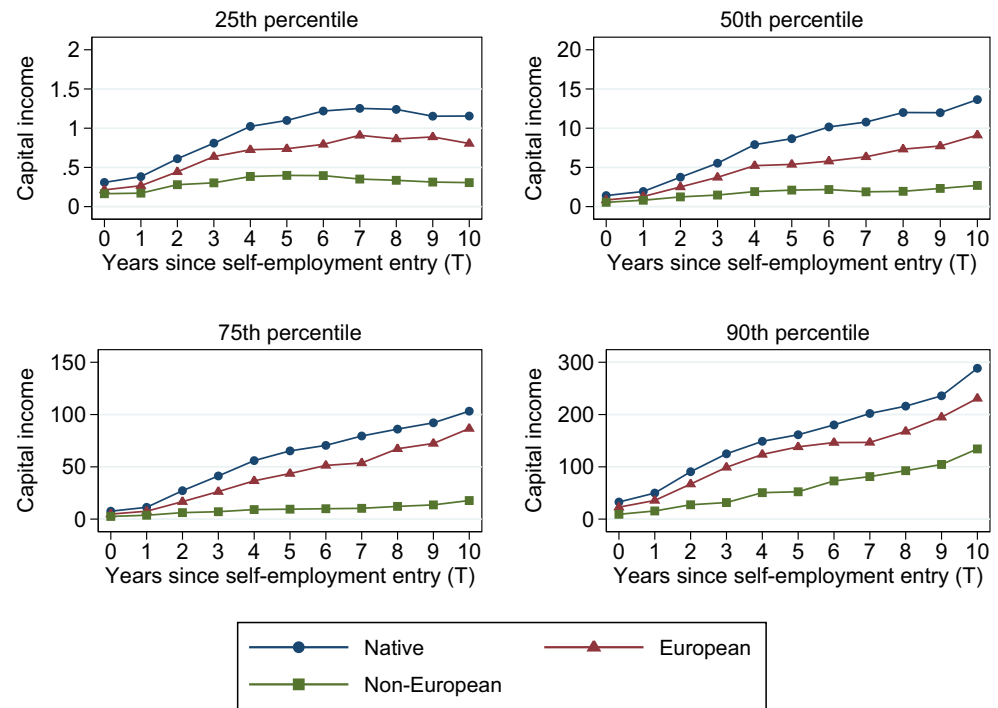

to their owners as the businesses grow. Another explanation could be that self-employed natives are better at obtaining a larger share of their self-employment compensation in the form of capital income, which is beneficial due to the typically lower marginal tax rate on capital income in the context of the Swedish dual-income tax system (where the taxation of capital income is separated from the taxation of labor income). ${ }^{23}$

Finally, we have repeated Figs. 2, 3, 4, and 5 where we compare natives with immigrants, dividing up the analysis depending on if these immigrants arrived to Sweden before or after (or in) 1990. These figures can be found in Figs. 25, 26, 27, 28, 29, 30, 31, and 32 in the Appendix and show that cohorts that arrived to Sweden before 1990 generally have a more positive long-term development of labor and capital income relative to more recent cohorts, especially among European immigrants.

\subsection{Regression evidence}

We now turn to a regression approach to examine immigrant-native differences in average labor income and capital income over the course of selfemployment. The benefit of the regression approach is

\footnotetext{
${ }^{23}$ The reason could be immigrant-native differences in knowledge about the tax system, in line with the results of Bastani et al. (2020) who document important immigrant-native differences in tax filing even among individuals with relatively high incomes.
}

that we can control for a set of individual characteristics at the year of self-employment entry. We focus on the following specification:

$$
\begin{aligned}
\log Y_{i}= & \alpha+\beta \text { European }_{i}+\gamma \text { NonEuropean }_{i} \\
& +X_{i} \delta+\epsilon_{i} .
\end{aligned}
$$

The outcome variable $\log Y_{i}$ is the logarithm of individual average income over the period $T=0$ to $T=10$. The purpose of focusing on 10-year averages is to approximate a "permanent" income measure for the long-term self-employed. $X_{i}$ represents a vector of control variables, including age, gender, marital status, education, and the number of children in the household under age 18, and $\epsilon_{i}$ is an error term. The variables of interest are the dummies European Eu $_{i}$ and NonEuropean $i$ that indicate whether a self-employed person is a European or a non-European immigrant, with the reference group being self-employed natives. The estimates of the coefficients $\beta$ and $\gamma$ capture immigrant-native difference in average earnings.

Table 3 presents the estimated coefficients of interest for each outcome variable, with and without controls. $^{24}$ The results in specification (2), with controls, show that, relative to natives, average labor income is about $24 \%$ lower for European immigrants and about $41 \%$ lower for non-European immigrants. Mirroring the graphical evidence, the largest

\footnotetext{
${ }^{24}$ The coefficients of the control variables are shown in the extended table, Table 13, in Appendix B.
} 
Fig. 5 The share of self-employed who have an incorporated business and work in an industry with low barriers to entry
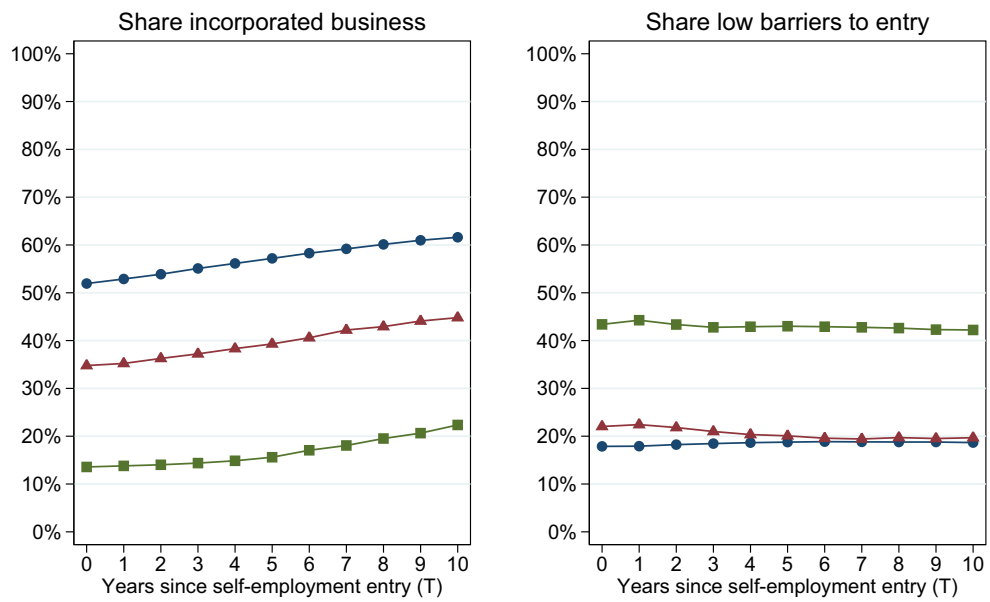

immigrant-native differences are found for capital income, which is around 60\% lower for European immigrants and around $90 \%$ lower for non-European immigrants. ${ }^{25}$ The average income gap between immigrants and natives may not fully reflect how the gap looks like in different parts of the outcome distribution. Therefore, in Table 12 in Appendix B, we re-run the above specification using quantile regression. For both labor and capital income, the results show that the earnings gap is largest in the bottom of the distribution (at the 25th percentile) and smallest at the top of the distribution (at the 75th percentile).

Notice that the longitudinal nature of the data also allows us to perform a traditional panel data analysis. However, the major advantage of using 10-year averages is that this approximates a measure of permanent long-term income for the long-term self-employed in our sample. This cross-sectional approach also allows us to smooth out year-specific fluctuations in labor and capital income, which is especially important in the case of capital income, due to the volatile nature of capital income flows. However, as a robustness check, we have also performed a traditional panel data analysis in Table 16 in Appendix B. This analysis confirms

\footnotetext{
$\overline{{ }^{25} \text { We exclude }}$ individuals who have zero capital income throughout the 10-year period. As a result, 3, 11, and $24 \%$ of natives, and European and non-European immigrants, respectively, are excluded from the analysis.
}

the large immigrant-native differences in both labor and capital incomes. ${ }^{26}$

Figure 5 showed that there are large immigrantnative differences in terms of the likelihood to have an incorporated firm and the likelihood to have a firm in an industry with low barriers to entry. It is therefore interesting to estimate the earnings gap when splitting the sample along these dimensions. Table 4 shows that for both labor income and capital income, the earnings gap between self-employed natives and immigrants remains large when restricting the analysis to either individuals with the same corporate form or to individuals who operate in industries with similar barriers to entry. However, the immigrant-native gap is larger among self-employed with unincorporated firms and firms in industries with low barriers to entry.

One key element for the success of self-employment activities is country-specific human capital which is accumulated by immigrants by spending time in the host country. In our sample, at the time of selfemployment entry, European immigrants have stayed in Sweden for about 20 years and non-European immigrants have stayed in Sweden for about 14 years. Thus, the two immigrant groups differ not only in

\footnotetext{
${ }^{26}$ The point estimates for labor income are very close to the corresponding estimates in column 2 of Table 3. For capital income, the estimated coefficients in Table 16 are smaller than the corresponding coefficients in column 4 of Table 3, but the immigrant-native gap remains large and significant.
} 
Table 3 Immigrant-native logarithmic earnings differences

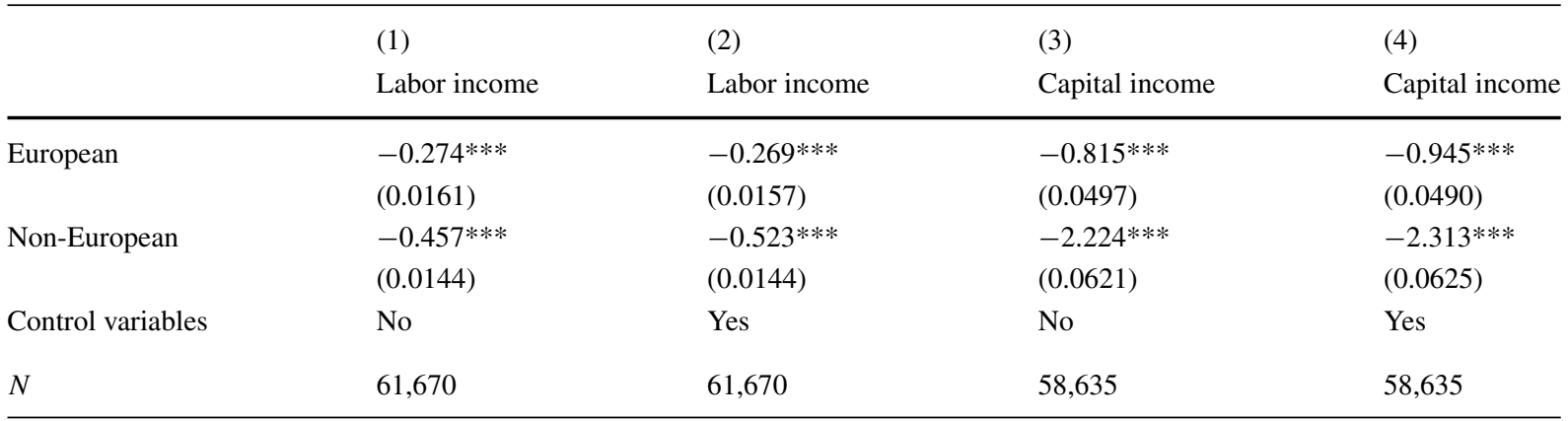

$*$, **, and $* * *$ denote the significance on the 10,5, and 1 percent levels, respectively. Robust standard errors are shown in the parentheses. The control variables are determined at the year of self-employment entry: age, gender, high school, college, marital status, and number of children at household under age 18

terms of their country of birth, but also in terms of their length of exposure to the host country. ${ }^{27}$ Table 5 repeats the analysis in Table 3 dividing up the analysis depending on the length of stay in Sweden at the time of self-employment entry. The results show that for both European and non-European immigrants, the estimated income differences relative to natives decrease with respect to the duration of stay in the host country. The results suggest that country-specific human capital at the time of self-employment entry can have a long-run impact on business performance and earnings. ${ }^{28}$ However, it is important to note that there are substantial differences among natives and immigrants, even among those who have stayed a very

\footnotetext{
${ }^{27}$ The distributions of length of stay in Sweden at the time of self-employment entry for the two immigrant groups are shown in Fig. 18 in Appendix B. We further present the evolution of labor and capital incomes for immigrants with different lengths of stay in Sweden at the time of self-employment entry in Figs. 19, 20, 21, 22, 23, and 24 in Appendix A.

${ }^{28}$ The level of education at the time of self-employment entry is also likely to be important. Table 14 in the Appendix analyzes earnings differences between natives and immigrants for different levels of education at the time of self-employment entry. Interestingly, the estimated interaction effects between the immigration dummies and the dummies for higher education are negative, indicating that the immigrant-native differences in long-term self-employment outcomes are larger among those who have higher education. A limitation of these results is that we can only observe the quantity and not the quality of education. In particular, we can not observe whether immigrants have obtained their higher education in Sweden or in their home country. Another aspect is that there is likely to be a higher mismatch among highly educated immigrants between their level of education and the type of businesses that they run, in relation to natives.
}

long time in Sweden before they start their business, especially in the case of non-European immigrants.

Of course, those who have stayed in Sweden for a long time naturally also belong to earlier cohorts of immigrant to Sweden. To shed further light on the role of immigration cohort, Table 6 presents a table similar to Table 5 that divides up the results depending on if the self-employed individual migrated to Sweden before or after $1990 .^{29}$ The results confirm the pattern observed in the graphical evidence, namely, that cohorts that arrived to Sweden before 1990 generally have better long-term outcomes. In fact, European immigrants who arrived before 1990 have long-term outcomes that are very similar to natives.

\subsection{Discussion}

The previous literature has found that native selfemployed in general have better economic outcomes than immigrant self-employed along a number of economic dimensions. This literature has mainly focused on the choice to become self-employed and shortrun self-employment outcomes. Our contribution is to take a long-term perspective, and also analyze important immigrant-native differences in the evolution of capital income along the course of self-employment.

Our graphical analysis showed that labor earnings for long-term self-employed natives and immigrants appear to converge over time, while capital income appears to be widening over time. Moreover, a regression analysis of long-run averages revealed that a substantial immigrant-native gap persists, even

\footnotetext{
${ }^{29}$ The year 1990 can be motivated based on the discussion in Section 2.
} 
Table 4 Immigrant-native logarithmic earnings differences by corporate form and industry

\begin{tabular}{|c|c|c|c|c|}
\hline & (1) & (2) & (3) & (4) \\
\hline & \multicolumn{2}{|l|}{ Labor income } & \multicolumn{2}{|l|}{ Capital income } \\
\hline Corporate form & Incorporated & Unincorporated & Incorporated & Unincorporated \\
\hline \multirow[t]{2}{*}{ European } & $-0.0606 * * *$ & $-0.184 * * *$ & $-0.237 * * *$ & $-0.723 * * *$ \\
\hline & $(0.0125)$ & $(0.0213)$ & $(0.0567)$ & $(0.0589)$ \\
\hline \multirow[t]{2}{*}{ Non-European } & $-0.216^{* * *}$ & $-0.272 * * *$ & $-0.716^{* * * *}$ & $-1.391 * * *$ \\
\hline & $(0.0238)$ & $(0.0162)$ & $(0.118)$ & $(0.0644)$ \\
\hline Control variables & Yes & Yes & Yes & Yes \\
\hline$N$ & 30,142 & 31,528 & 29,891 & 28,744 \\
\hline Barriers to entry & Low barrier & Non-low barrier & Low barrier & Non-low barrier \\
\hline \multirow[t]{2}{*}{ European } & $-0.283^{* * *}$ & $-0.255^{* * *}$ & $-1.329 * * *$ & $-0.820 * * *$ \\
\hline & $(0.031)$ & $(0.018)$ & $(0.110)$ & $(0.054)$ \\
\hline \multirow[t]{2}{*}{ Non-European } & $-0.564 * * *$ & $-0.446 * * *$ & $-2.672 * * *$ & $-1.940 * * *$ \\
\hline & $(0.022)$ & $(0.019)$ & $(0.099)$ & $(0.081)$ \\
\hline Control variables & Yes & Yes & Yes & Yes \\
\hline$N$ & 11,982 & 49,688 & 11,073 & 47,562 \\
\hline
\end{tabular}

$*, * *$, and $* * *$ denote the significance on the 10,5 , and 1 percent levels respectively. Robust standard errors are shown in the parentheses. The control variables are determined at the year of self-employment entry: age, gender, high school, college, marital status, and number of children at household under age 18

Table 5 Immigrant-native logarithmic earnings differences by duration of stay in Sweden at self-employment entry

\begin{tabular}{lll}
\hline & $(1)$ & $(2)$ \\
& Labor income & Capital income \\
\hline European $\leq 10$ years & $-0.546^{* * *}$ & $-2.032^{* * *}$ \\
& $(0.0306)$ & $(0.101)$ \\
European 10-20 years & $-0.271^{* * *}$ & $-0.964 * * *$ \\
& $(0.0297)$ & $(0.0913)$ \\
European $>20$ years & $-0.107^{* * *}$ & $-0.397 * * *$ \\
& $(0.0222)$ & $(0.0661)$ \\
Non-European $\leq 10$ years & $-0.641^{* * *}$ & $-3.287 * * *$ \\
& $(0.0233)$ & $(0.118)$ \\
Non-European 10-20 years & $-0.551^{* * *}$ & $-2.452^{* * *}$ \\
& $(0.0214)$ & $(0.0860)$ \\
Non-European $>20$ years & $-0.293^{* * *}$ & $-1.017 * * *$ \\
Control variables & Yes & Yes \\
$N$ & 61606 & 58575 \\
\hline
\end{tabular}

$*$, ** and $* * *$ denote the significance on the 10,5 and 1 percent level respectively. Robust standard error are shown in parenthesis. The control variables are determined at the year of self-employment entry, and are given by: age, gender, high school, college, marital status, and number of children in household under age 18. Compared to Table 3 , we lose a small number of observations due to the lack of information about the year of arrival in Sweden
Table 6 Immigrant-native logarithmic earnings differences by cohort

\begin{tabular}{cll}
\hline & $(1)$ & $(2)$ \\
& Labor income & Capital income \\
\hline European arrived before 1990 & $-0.140 * * *$ & $-0.496 * * *$ \\
& $(0.0199)$ & $(0.0586)$ \\
European arrived after 1990 & $-0.464 * * *$ & $-1.720 * * *$ \\
& $(0.0248)$ & $(0.0822)$ \\
Non-European arrived & $-0.421 * * *$ & $-1.663 * * *$ \\
before 1990 & $(0.0208)$ & $(0.0801)$ \\
Non-European arrived & $-0.625 * * *$ & $-3.122 * * *$ \\
after 1990 & $(0.0191)$ & $(0.0913)$ \\
Control variables & Yes & Yes \\
$N$ & 61606 & 58575 \\
\hline
\end{tabular}

$*$, ** and $* * *$ denote the significance on the 10,5 and 1 percent level respectively. Robust standard error are shown in parenthesis. The control variables are determined at the year of self-employment entry, and are given by: age, gender, high school, college, marital status, and number of children in household under age 18 . Compared to Table 3 , we lose a small number of observations due to the lack of information about the year of arrival in Sweden 
after controlling for different factors at the time of self-employment entry. The gap is more pronounced among those with unincorporated businesses, and the widest gap is found when comparing natives and nonEuropean immigrants, and when considering immigrants with a shorter duration of stay in Sweden at the time of self-employment entry or immigrants who arrived more recently to Sweden.

It is well-known that non-European immigrants have difficulties in the Swedish and many European labor markets. Hence, non-European immigrants are more likely than natives to be pushed into the selfemployment sector. This is also partly reflected in our results that show that a large number of non-European self-employed immigrants are working in low entry barrier sectors and choose to pursue their business activity in unincorporated firms. However, substantial immigrant-native differences remain even when we restrict attention to those who start the same type of business in the same type of industry. To obtain further insights into the determinants of these remaining differences, we turn to analyze our survey targeting the long-term self-employed.

\section{Survey evidence}

We now turn to our survey evidence. Section 5.1 starts by describing the background characteristics of the long-term self-employed individuals in our sample. The purpose is to understand what characterizes long-term self-employed individuals along background dimensions that are typically not available in register data, with a focus on highlighting immigrantnative differences. ${ }^{30}$ We then proceed to analyze the more specific questions of our survey, which fall into two broad categories: factors that contribute to long-term self-employment and self-employment success (Section 5.2) and obstacles facing the long-term self-employed (Section 5.3). ${ }^{31}$

\subsection{Background characteristics}

Table 7 describes the background characteristics of our survey respondents, focusing on individual and

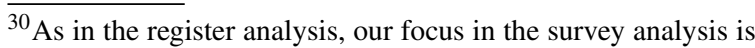
on first-generation immigrants.

${ }^{31}$ Table 18 in Appendix B provides a description of the variables.
}

family characteristics, business characteristics, language skills, working hours, and perspectives on selfemployment. The first three columns show the mean value for each variable for natives, and European and non-European immigrants. The subsequent two columns test for statistically significant differences between each of the two immigrant groups and the native reference group.

We begin by noticing that the average age at selfemployment entry is significantly higher among immigrants than that among natives. This holds true especially for non-European immigrants. An interesting question is whether there are immigrant-native differences in the inter-generational transmission of the choice to become self-employed and what role the family plays for the long-term self-employed. ${ }^{32} \mathrm{We}$ find that immigrants are in general less likely to have parents who are self-employed. ${ }^{33}$ This could reflect that immigrants are pushed into self-employment due to lack of better alternatives rather than being pulled into self-employment, by, for instance, family traditions. We also find that non-European immigrants are less likely than natives to have family members or relatives work in their business.

Turning to business characteristics, we find that immigrant-owned businesses are on all accounts much more likely to interact with people with a foreign background, in the form of either employee relationships, or relationship with suppliers or customers. ${ }^{34}$ The difference relative to natives is strongest for nonEuropean immigrants. Furthermore, compared with non-European immigrants, natives report to be more likely to have a personal relationship with their customers.

Language skills are obviously very important for immigrants to succeed in the labor market. However, it is unclear to which extent language skills play

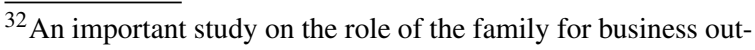
comes is Fairlie and Robb (2007a) who found that the success of small business owners was only weakly correlated with having a self-employed family member, but strongly correlated with prior work experience in a family member's business.

${ }^{33}$ This is in contrast to what has been found for second- and third-generation immigrants in Sweden; see Andersson and Hammarstedt (2010).

${ }^{34}$ Previous research has previously documented a correlation between the birth country of managers and their employees; see, e.g. Åslund et al. (2014) and Hammarstedt and Miao (2020).
} 
Table 7 Background characteristics of individuals in the survey-sample

\begin{tabular}{|c|c|c|c|c|c|c|}
\hline & (1) & $(2)$ & (3) & $(2)-(1)$ & $(3)-(1)$ & (4) \\
\hline & Native & European & Non-European & Eur. vs. Nat. & Non-Eur. vs. Nat. & Obs \\
\hline \multicolumn{7}{|l|}{ Individual and family characteristics } \\
\hline Age at first self-employment entry & 33.382 & 34.628 & 35.011 & $1.246 * * *$ & $1.629 * * *$ & 6280 \\
\hline Parents self-employed & 0.498 & 0.306 & 0.364 & $-0.192 * * *$ & $-0.134 * * *$ & 6683 \\
\hline Family or relatives work in the business & 0.417 & 0.394 & 0.379 & -0.023 & $-0.038 * *$ & 6578 \\
\hline \multicolumn{7}{|l|}{ Business characteristics } \\
\hline Foreign-born employees & 0.042 & 0.340 & 0.454 & $0.298 * * *$ & $0.412 * * *$ & 6279 \\
\hline Foreign-born business suppliers & 0.066 & 0.179 & 0.288 & $0.113 * * *$ & $0.222 * * *$ & 6444 \\
\hline Foreign-born customers & 0.074 & 0.167 & 0.244 & $0.094 * * *$ & $0.170 * * *$ & 6498 \\
\hline Personal relationship with customers & 0.449 & 0.428 & 0.312 & -.021 & $-0.137 * * *$ & 6592 \\
\hline \multicolumn{7}{|l|}{ Language skills } \\
\hline High proficiency in Swedish & 0.816 & 0.645 & 0.410 & $-0.171 * * *$ & $-0.406 * * *$ & 6649 \\
\hline High proficiency in English & 0.648 & 0.602 & 0.512 & $-0.046^{* *}$ & $-0.137 * * *$ & 6643 \\
\hline \multicolumn{7}{|l|}{ Working hours } \\
\hline Hours of work & 42.375 & 42.259 & 47.154 & -0.115 & $4.779 * * *$ & 6559 \\
\hline Working as an employee in another job & 0.049 & 0.056 & 0.088 & 0.007 & $0.039 * * *$ & 6560 \\
\hline Hours of work in other job $\dagger$ & 2.210 & 2.817 & 3.208 & $0.607 * *$ & $0.998 * * *$ & 459 \\
\hline Husband/wife working hours in business & 28.623 & 32.114 & 36.423 & $3.492 * * *$ & $7.800 * * *$ & 2487 \\
\hline \multicolumn{7}{|l|}{ Perspectives on self-employment } \\
\hline Enjoy being self-employed & 0.937 & 0.909 & 0.777 & $-0.028 * *$ & $-0.160 * * *$ & 6608 \\
\hline Prefer to be employee & 0.059 & 0.123 & 0.275 & $0.064 * * *$ & $0.216^{* * *}$ & 6135 \\
\hline Luck most important for economic success & 0.136 & 0.205 & 0.290 & $0.069 * * *$ & $0.154 * * *$ & 6554 \\
\hline Achieved goals & 0.496 & 0.477 & 0.359 & -0.019 & $-0.137 * * *$ & 6629 \\
\hline Self-employed in the next 5 years (yes/no) & 0.584 & 0.565 & 0.650 & -0.019 & $0.066 * * *$ & 6615 \\
\hline
\end{tabular}

Mean coefficients; $* * *$ and $* * *$ denote the significance on the 10,5 and 1 percent level respectively. ( $\dagger$ ) In this question, the sample is restricted to those who report working as an employee in another job

a role for the long-term self-employed and whether there are differences between immigrant groups. We find that compared to natives, non-European immigrants are about 40 percentage points less likely to be proficient in Swedish while the corresponding difference between European immigrants and natives is only about 17 percentage points. We also note that non-European immigrants are also less likely to be highly proficient in English compared to natives and European immigrants.

Regarding hours of work, we find no differences in terms of hours of work between natives and European immigrants. However, non-European immigrants work much more, on average almost five more hours per week. This is despite the fact that non-European immigrants, on average, generally earn much less than natives. The proportion of individuals among the long-term self-employed who have another job is however small among both natives and immigrants. ${ }^{35}$ We also see that among those who report that their partner works in their business, immigrants report that their partner works longer hours than natives do, especially in the case of non-European immigrants. Thus, a clear message is that non-European long-term

\footnotetext{
${ }^{35}$ However, non-European immigrants who do have a job on the side also tend to work more hours on this job as well.
} 
self-employed immigrants, and their partners, work much more than their native and European counterparts.

A specific purpose of the survey was to go beyond the traditional monetary measures of self-employment success to obtain a broader view of immigrant-native differences in self-employment success. In particular, we asked respondents whether they enjoy being selfemployed, whether they instead would have preferred to be employed as a regular employee, whether they consider themselves to have achieved their goals as self-employed and whether they think that they will be self-employed five years into the future. What we find is that the attitude towards self-employment differs dramatically among self-employed natives and immigrants, even though we focus on individuals who all share a long history of self-employment. Compared to natives, immigrants consider self-employment to be less enjoyable, would rather be wage employed, and to a lesser extent feel that they have achieved their goals. This is line with the common explanation that many immigrants are pushed into self-employment due to the lack of better labor market opportunities. Interestingly, immigrants also feel, to a much greater extent than natives, that luck is more important than hard work for economic success.

To sum up, we find large immigrant-native differences in several important dimensions. The most striking ones are those that relate to working hours and perspectives on self-employment.

\subsection{Perceived success factors}

Table 8 analyzes how the respondents view different factors that could be important in explaining their long-term success in self-employment. The questions focus on the role of the family, social networks, work experience, and access to capital.

Between 25 and $30 \%$ of respondents perceive their partner to be important for the success of their business. Non-Europeans consider their partners to be the most important and the difference relative to natives is statistically significant. Children are considered to be less important in general, with only about 11 to $13 \%$ of respondents considering them to be important for the success of their business. There is a small tendency for non-European immigrants to consider children to be more important, but the difference relative to the other groups is not statistically significant. Relatives are considered to be less important than both partners and children, but here there is still a clear immigrant-native difference, with around $10 \%$ of non-European immigrants considering children to be important for the success of their business, whereas the corresponding share for natives is only around 6\%.

Previous literature has found that social networks are important not only in the startup phase of a business, but also for its long-term performance. Our survey shows that former employers and colleagues are important for both self-employed natives and immigrants, but natives value them much more, especially compared to non-European immigrants. Previous business partners appear however to be roughly equally important to immigrants and natives, with around $20 \%$ of respondents expressing that such connections are important for their business. Interestingly, a significantly higher share of self-employed non-European immigrants consider previous classmates, neighbors, and friends to be important. The answers to the questions of the importance of the social network suggest that there are potentially large immigrant-native differences in terms of how important networks outside the workplace are considered for the success in self-employment. ${ }^{36}$ The fact that primarily non-European immigrants seem to, relative to natives and European immigrants, lack social networks with a strong connection to the labor market, could be one explanation for their worse long-term self-employment outcomes.

An important question is to which extent human capital acquired in the home country is transferable to the new host country as individuals migrate and to which extent education acquired in the host country is perceived as valuable for the success in self-employment. Both European and non-European immigrants consider their education in their home country to be valuable, with no clear differences between the two groups of immigrants. Most respondents also consider having an education in the host country (Sweden) to be an important advantage. The shares are 55 and $63 \%$, respectively for European and non-European immigrants, which should be compared to the share among natives, which is $68 \%$.

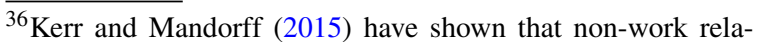
tionships facilitate the acquisition of sector-specific skills and represent one important factor contributing to immigrant-native patterns in entrepreneurship.
} 
Table 8 Factors important for long-term self-employment

\begin{tabular}{|c|c|c|c|c|c|c|}
\hline & (1) & (2) & (3) & $(2)-(1)$ & (3)-(1) & (4) \\
\hline & Native & European & Non-European & Eur. vs. Nat. & Non-Eur. vs. Nat. & Obs \\
\hline \multicolumn{7}{|c|}{ Role of family } \\
\hline \multicolumn{7}{|c|}{ How important are the following people for your business? } \\
\hline Partner & 0.251 & 0.271 & 0.307 & 0.020 & $0.056 * * *$ & 6336 \\
\hline Children & 0.118 & 0.110 & 0.131 & -0.008 & 0.013 & 6056 \\
\hline Relatives & 0.063 & 0.047 & 0.097 & $-0.016^{* *}$ & $0.034 * * *$ & 5988 \\
\hline
\end{tabular}

Social network

How important are the following people in contributing your businesses?

$\begin{array}{lllllll}\text { Past employers } & 0.365 & 0.326 & 0.238 & -0.039 * * & -0.107 * * * & 6236 \\ \text { Past colleagues } & 0.302 & 0.255 & 0.249 & -0.047 * * & -0.053^{* * *} & 6128 \\ \text { Past classmates } & 0.0760 & 0.0690 & 0.115 & -0.007 & 0.039 * * * & 5987 \\ \text { Previous business partners } & 0.197 & 0.180 & 0.182 & -0.017 & -0.015 & 6049 \\ \text { Neighbors and friends } & 0.154 & 0.153 & 0.189 & -0.001 & 0.035^{* *} & 6153\end{array}$

Education and past work experience

How important are the following types of experience for your business?

$\begin{array}{llllllr}\text { Education in Sweden } & 0.684 & 0.555 & 0.630 & -0.129 * * * & -0.054 * * & 6338 \\ \text { Education in home-country } \dagger & - & 0.472 & 0.503 & - & - & 3599 \\ \text { Work experience in Sweden } & 0.607 & 0.589 & 0.556 & -0.017 & -0.051^{* *} & 6185 \\ \text { Work experience in home-country } \dagger & - & 0.334 & 0.381 & - & - & 3557\end{array}$

Access to capital

How important have the following sources of capital been for the funding of your business?

\begin{tabular}{|c|c|c|c|c|c|c|}
\hline Bank lending & 0.436 & 0.376 & 0.423 & $-0.059 * * *$ & -0.013 & 6401 \\
\hline Inheritance & 0.043 & 0.043 & 0.083 & -0.000 & $0.040 * * *$ & 6146 \\
\hline Gift from relatives & 0.031 & 0.035 & 0.101 & 0.004 & $0.070 * * *$ & 6136 \\
\hline Borrowing from relatives & 0.046 & 0.090 & 0.221 & $0.044 * * *$ & $0.175 * * *$ & 6172 \\
\hline Gift from friends & 0.006 & 0.020 & 0.061 & $0.014 * * *$ & $0.055 * * *$ & 6110 \\
\hline Borrowing from friends & 0.018 & 0.061 & 0.166 & $0.043 * * *$ & $0.148 * * *$ & 6132 \\
\hline Salaries from other jobs & 0.079 & 0.100 & 0.124 & $0.021 * *$ & $0.045 * * *$ & 6146 \\
\hline State subsidy & 0.077 & 0.106 & 0.205 & $0.028 * *$ & $0.128 * * *$ & 6181 \\
\hline Other sources & 0.042 & 0.048 & 0.097 & 0.006 & $0.055^{* * *}$ & 614 \\
\hline
\end{tabular}

Mean coefficients; *,** and $* * *$ denote the significance on the 10,5 and 1 percent level respectively. ( $\dagger$ ) In these questions, the sample is restricted to immigrants

Regarding past work experience in the Swedish labor market, about $60 \%$ of natives, $59 \%$ of European immigrants, and $55 \%$ of non-European immigrants find this factor to be important. Overall, and quite naturally, we see that natives value education and working experience more than immigrants. This is one explanation behind the the fact that a significant proportion of self-employed non-European immigrants work in industries with low barriers to entry, where the human capital requirements are smaller.
Previous research has found that natives and immigrants differ in terms of their ability to obtain capital to fund the startup and growth of their businesses. ${ }^{37}$ From Table 8, we see that both self-employed natives and immigrants consider bank loans to be an important source of capital, although European immigrants weight the importance less than natives. Furthermore,

\footnotetext{
${ }^{37}$ See, e.g., Blanchard et al. (2008), Asiedu et al. (2012), and Aldén and Hammarstedt (2016).
} 
Table 9 Obstacles facing the long-term self-employed

\begin{tabular}{|c|c|c|c|c|c|c|}
\hline & (1) & (2) & (3) & (2)-(1) & (3)-(1) & (4) \\
\hline & Native & European & Non-European & Eur. vs. Nat. & Non-Eur. vs. Nat. & Obs \\
\hline \multicolumn{7}{|c|}{ How large of a concern are the following factors for your business? } \\
\hline Bureaucracy & 0.487 & 0.407 & 0.425 & $-0.080 * * *$ & $-0.062 * * *$ & 6260 \\
\hline High taxes & 0.643 & 0.639 & 0.720 & -0.004 & $0.077 * * *$ & 6428 \\
\hline High salaries & 0.299 & 0.318 & 0.477 & 0.019 & $0.178 * * *$ & 6047 \\
\hline Access to capital & 0.271 & 0.310 & 0.407 & $0.039 * *$ & $0.136 * * *$ & 6155 \\
\hline Tax complexity & 0.351 & 0.336 & 0.423 & -0.014 & $0.072 * * *$ & 6234 \\
\hline Finding employees & 0.374 & 0.362 & 0.436 & -0.012 & $0.062 * * *$ & 6095 \\
\hline Reaching customers & 0.173 & 0.226 & 0.313 & $0.053 * * *$ & $0.140 * * *$ & 6228 \\
\hline Suppliers & 0.044 & 0.071 & 0.105 & $0.027 * *$ & $0.061 * * *$ & 6174 \\
\hline Crime & 0.111 & 0.106 & 0.197 & -0.005 & $0.086 * * *$ & 6168 \\
\hline
\end{tabular}

Mean coefficients; *,** and $* * *$ denote statistical significance at the 10,5 and 1 percent level, respectively

we find that immigrants, particularly non-European immigrants, are more likely to consider other sources of finance, to be important.

\subsection{Perceived obstacles}

Our survey contained several questions with the purpose of identifying immigrant-native differences in terms of how respondents perceive and rank the importance of different obstacles to self-employment success. The results are shown in Table 9. Overall, we find that non-European immigrants experience more obstacles than natives do. In particular, they perceive high taxes, high salaries, access to capital, tax complexity, and finding appropriate employees to be more of a problem relative to natives, and often also in comparison to European immigrants.

Our results show that high taxes and tax complexity are perceived to be, relative to natives, more problematic among non-European immigrants but not among European immigrants. One natural potential explanation for this is that non-European immigrants are less familiar with European tax systems that share many common features. The immigrant-native divergence in the perceptions about taxes can have important implications since governments often use tax policy to stimulate entrepreneurship. If there are immigrant-native differences in terms of the understanding of the host country's tax system (which some research seems to indicate is the case; see e.g., Bastani et al. 2020), such measures can potentially exacerbate the immigrant-native differences in long-term self-employment outcomes that we have documented in this paper. ${ }^{38} \mathrm{We}$ also see that that self-employed non-European immigrants have more difficulties in finding employees. This can be due to several factors, such as ethnically segregated hiring networks or ethnic preferences among employees (see, e.g., Giuliano et al. 2009).

\section{Concluding remarks}

We have studied immigrant-native differences in longterm self-employment using a combination of administrative population registers and a unique survey targeting a large representative sample of self-employed immigrants and natives.

Our register analysis has placed a special emphasis on the evolution of labor and capital incomes during the first 10 years following self-employment entry, and suggests that natives are more successful than nonEuropean immigrants along key dimensions in the

\footnotetext{
${ }^{38}$ For example, one particular complex part of the tax system facing self-employed individuals who contemplate incorporating their business is the corporation tax. Da Rin et al. (2011) have shown that the corporate income tax affects both the selfemployment entry decision and the characteristics of the entering firms. There can also be a relationship between immigrantnative differences in the sensitivity to personal income taxation and immigrant-native differences in the decision to incorporate the business due to the possibility for tax planning with the context of the Swedish dual income tax system (see Alstadsæter \& Jacob 2016 for an overview of income shifting in Sweden).
} 
sense of having a stronger evolution of labor income, and a much sharper increase in capital income, over the course of self-employment. The only exception to this pattern are self-employed individuals with incorporated firms, where we find small immigrant-native differences in the top of the distribution of labor and capital income. Furthermore, while immigrant-native differences in labor income, on average, seem to converge over the course of self-employment, there is no such convergence for capital income. When analyzing 10-year averages of individuals' labor income and capital income trajectories in a regression framework, we find that substantial long-term immigrant-native differences remain, even after controlling for several factors at the point of self-employment entry.

Our survey data allowed us to obtain insights into what can explain these differences, and gain further insights into the role of immigrant background for long-term self-employment outcomes. The results show that self-employed immigrants experience more problems and earn less, but work harder than selfemployed natives. They also have a less personal relation to their customers, do not enjoy their work as much as natives, and appear to have different perspectives on self-employment in general. Finally, while self-employed natives have a stronger network of former employers and colleagues, self-employed immigrants more often rely on help from their family and relatives in their self-employment activities.

To date, much of the academic and policy discussion have focused on immigrant-native differences in the decision to become self-employed and shortrun self-employment outcomes. This discussion has highlighted important immigrant-native differences in the success of self-employment activities, and has also highlighted the fact that natives and immigrants face different obstacles and have different motives for becoming self-employed. We confirm the importance of the factors highlighted in this discussion, but we also add new knowledge to the research area regarding immigrant self-employment, and we conclude that the immigrant-native differences in self-employment activities often documented in previous research also exist when we take a long-term perspective on this issue.

Acknowledgements We are grateful to two anonymous referees for their helpful comments. The data that support the findings of this study are provided by Statistics Sweden and are covered by secrecy, but the anonymized microdata can be accessed following a confidentiality assessment, provided that Statistics Sweden considers that the researcher has the grounds to process the data (see https://www.scb.se/ en/services/guidance-for-researchersand-universities/ for more information). In addition, one has to to apply for permission from the Swedish Ethical Review Authority (https:// etikprovningsmyndigheten.se/). The authors are willing to assist in the process of obtaining the data.

Funding Open access funding provided by Uppsala University. Financial support was received from Familjen Kamprads Stiftelse.

\section{Appendix A: Appendix figures}
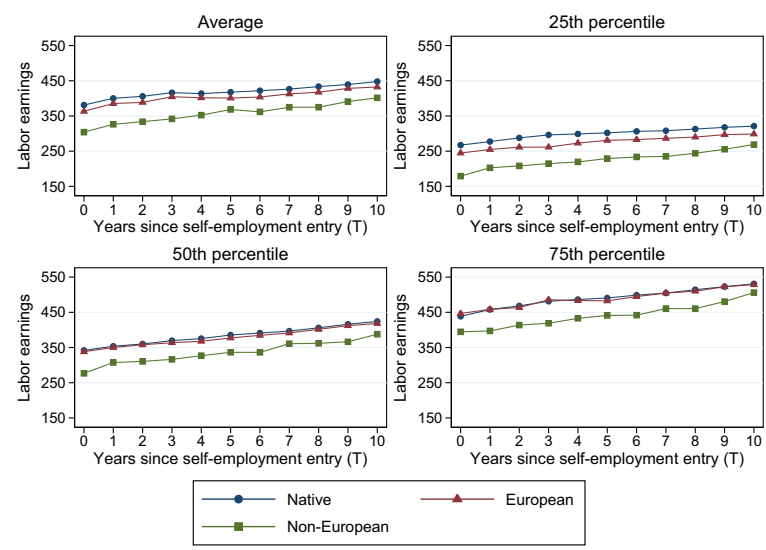

Fig. 6 Evolution of labor income among those who start an incorporated business
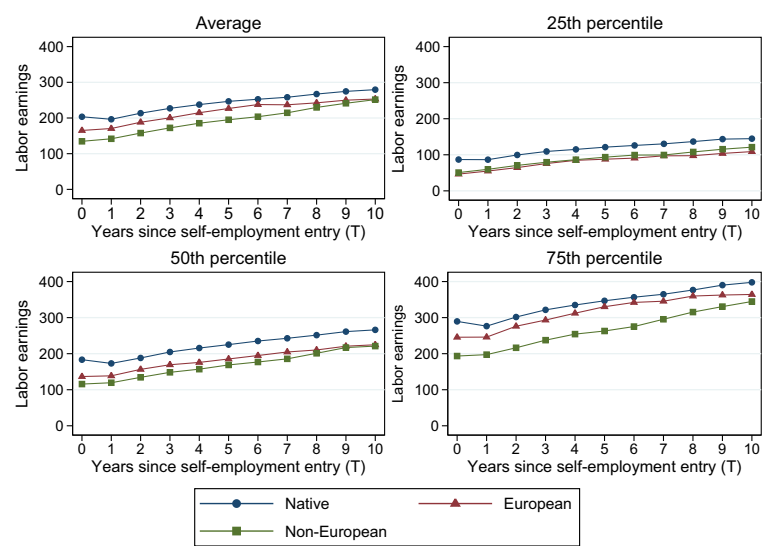

Fig. 7 Evolution of labor income among those who start an unincorporated business 
Fig. 8 Average capital income and share with positive capital income among among those who start an incorporated business

Fig. 9 Evolution of capital income among those who start an incorporated business, conditioning on positive capital income

Fig. 10 Average capital income and share with positive capital income among those who start an unincorporated business
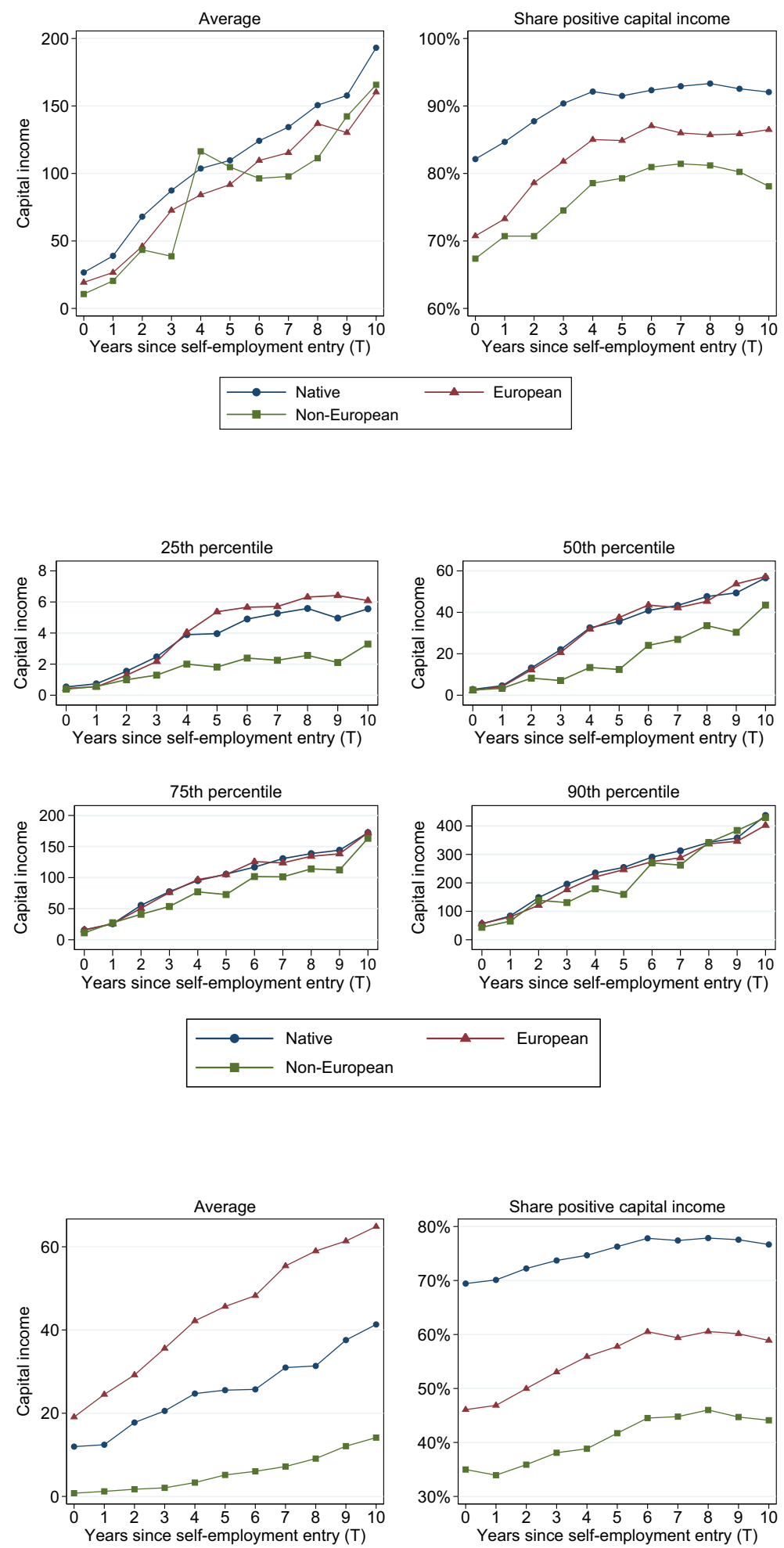

$\longrightarrow$ Native $\quad \longrightarrow$ European 
Fig. 11 Evolution of capital income among those who start an unincorporated business, conditioning on positive capital income
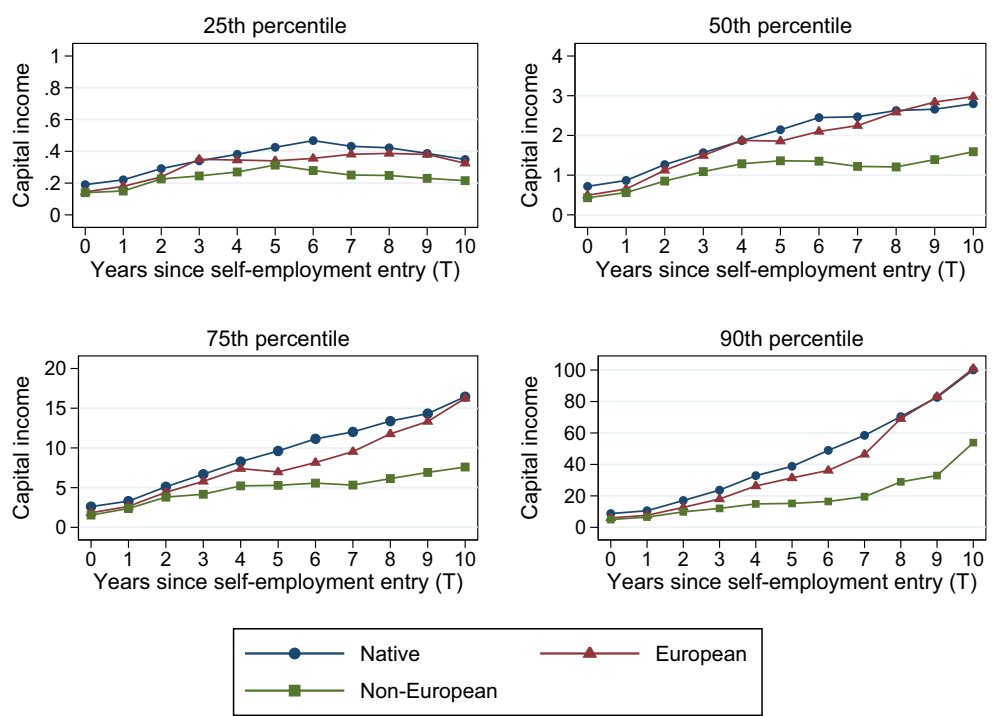

Fig. 12 Evolution of labor income among those who start a business in an industry with low barriers to entry
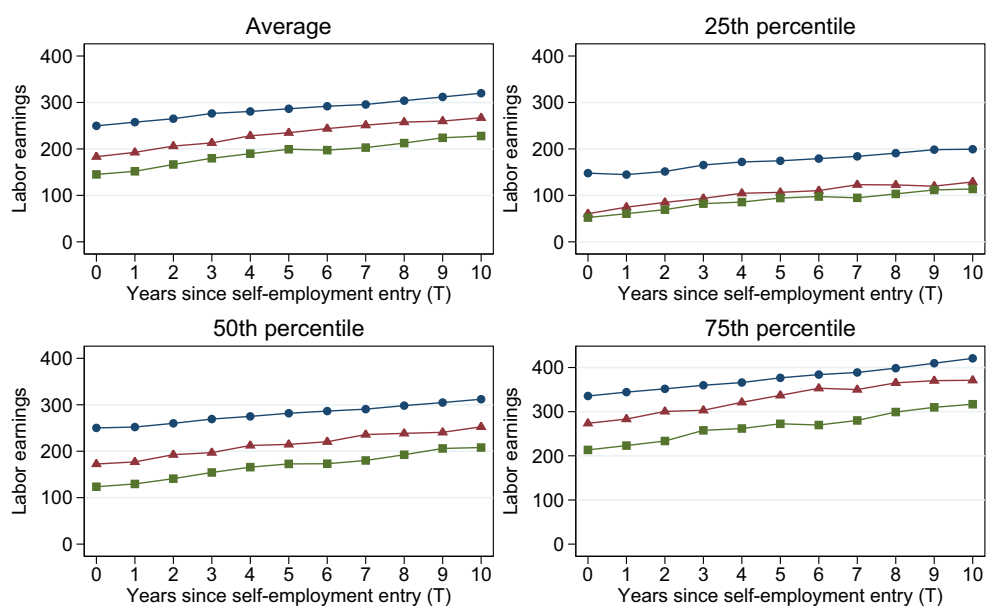
Fig. 13 Evolution of labor income among those who start a business in a non-low barrier industry

Fig. 14 Average capital income and share with positive capital income among those who start a business in an industry with low barriers to entry

Fig. 15 Evolution of capital income among those who start a business in an industry with low barriers to entry, conditioning on positive capital income
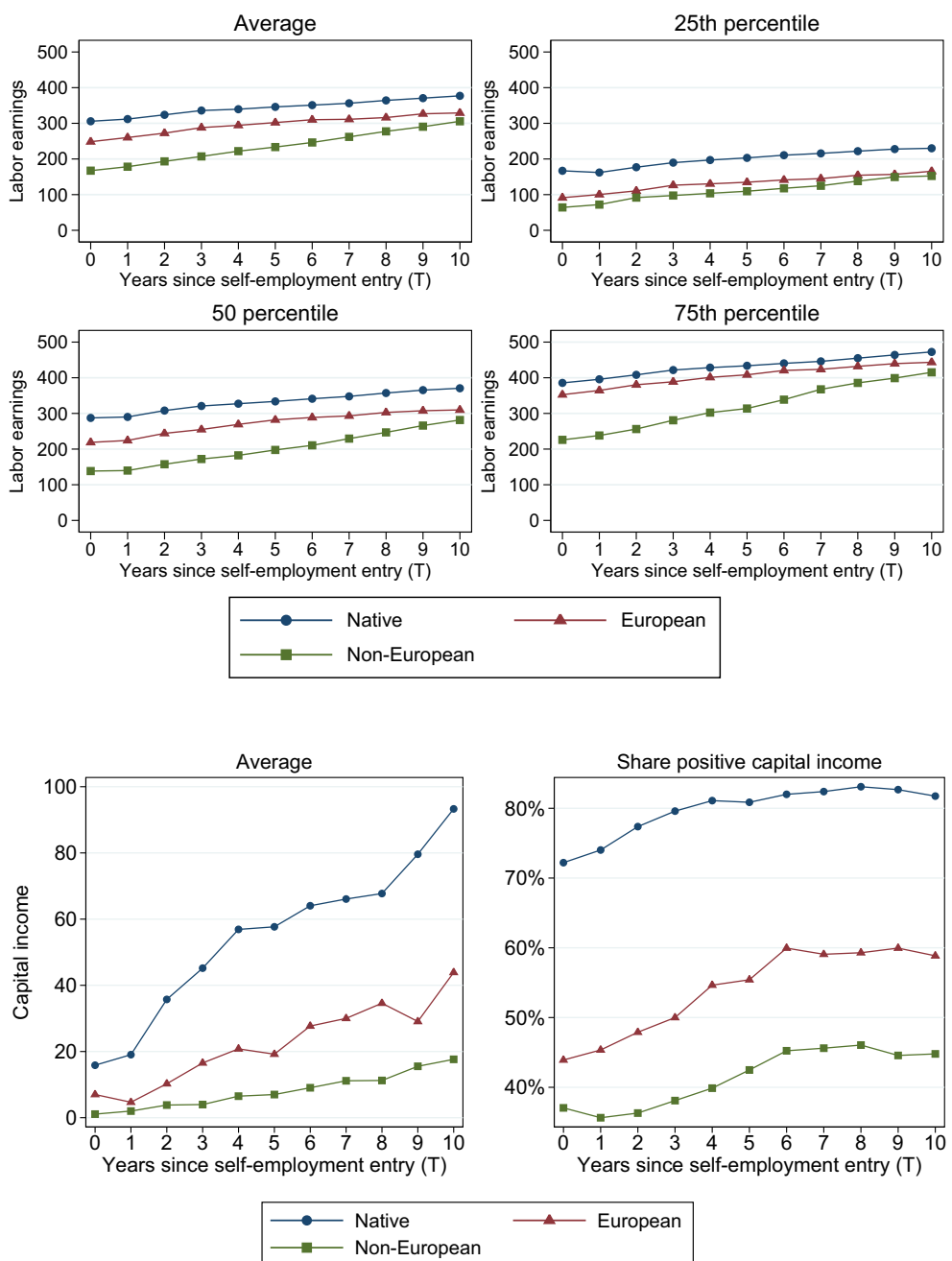

$\longrightarrow$ European
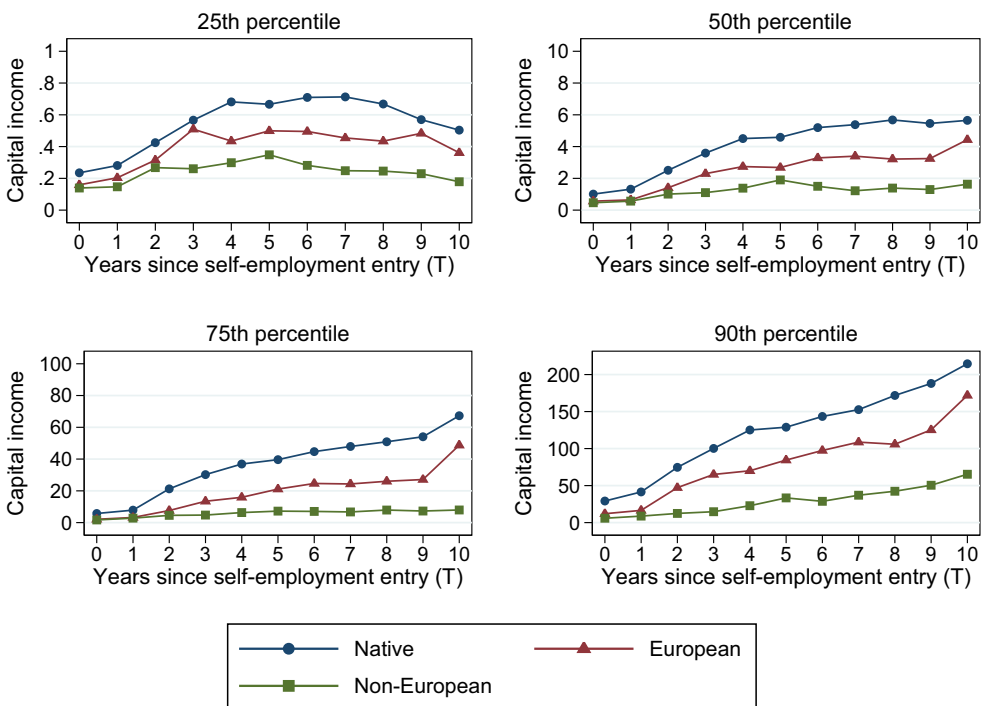
Fig. 16 Average capital income and share with positive capital income among those who start a business in a non-low barrier industry
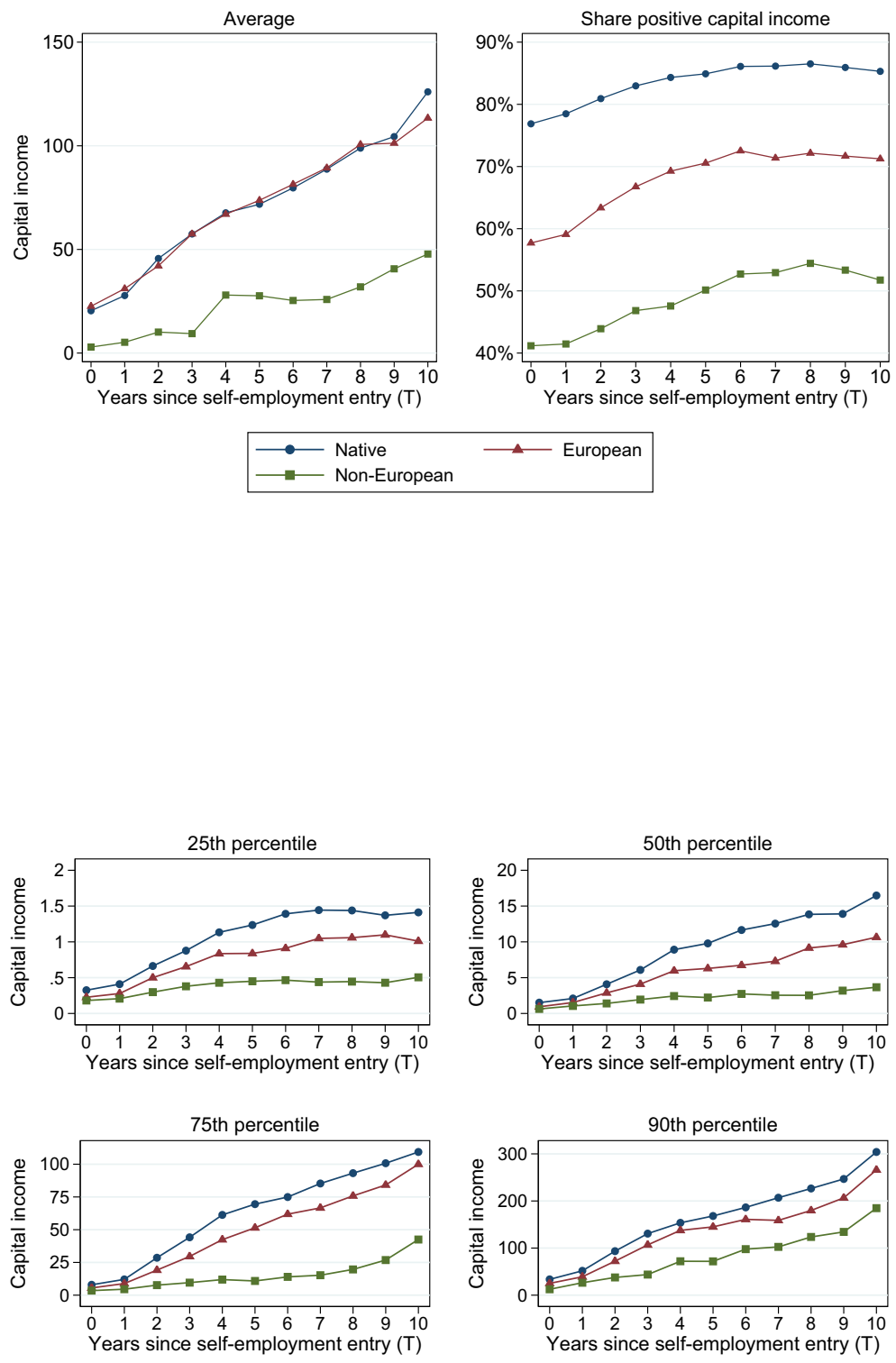

Fig. 17 Evolution of capital income among those who start a business in a non-low barrier industry, conditioning on positive capital income 
Fig. 18 Distribution of length of stay in Sweden at time of self-employment entry

Fig. 19 Evolution of labor income among natives and European immigrants by length of stay in Sweden at time of self-employment entry
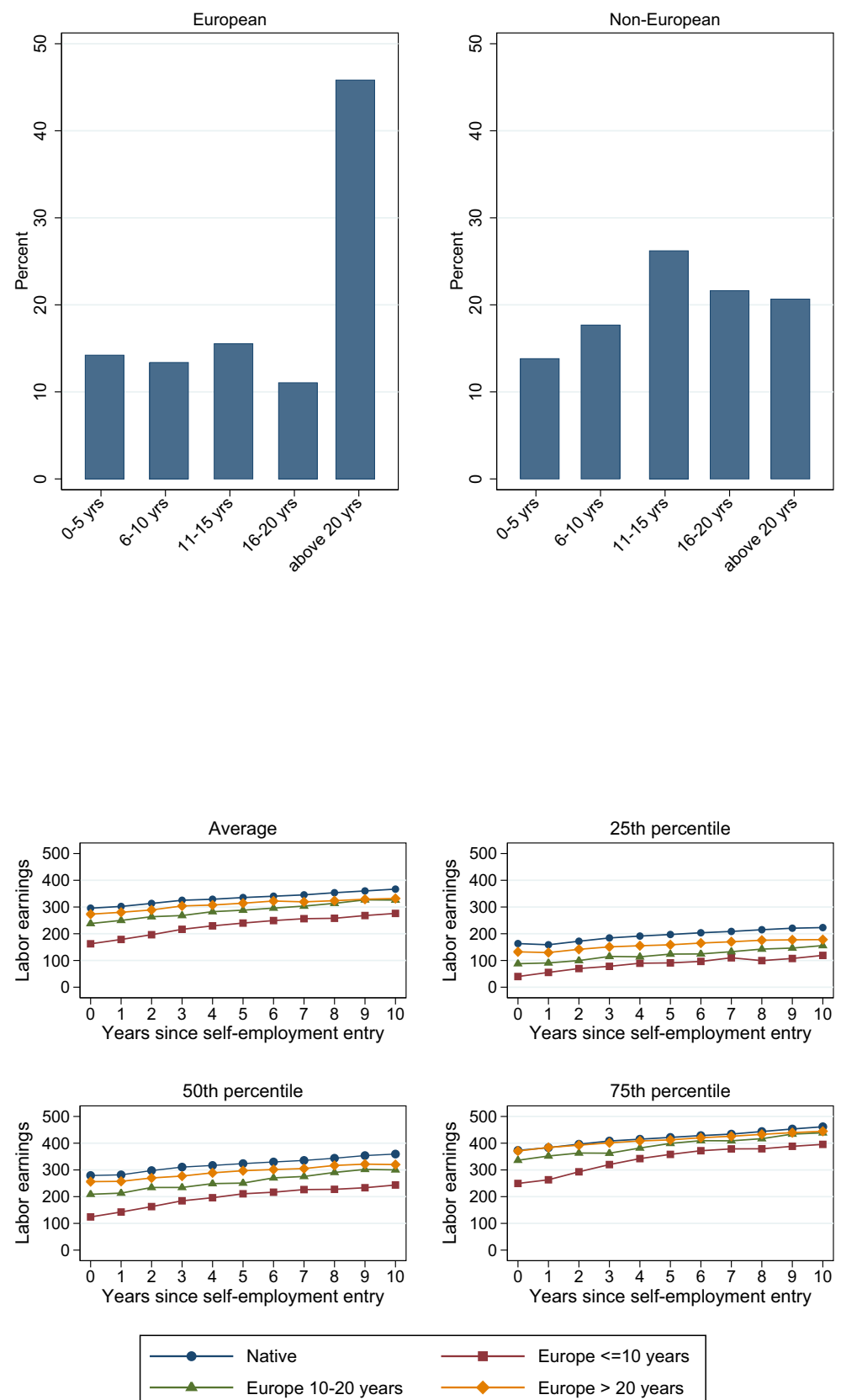
Fig. 20 Evolution of labor income among natives and non-European immigrants by length of stay in Sweden at time of self-employment entry

Fig. 21 Average capital income and share with positive capital income among natives and European immigrants by length of stay in Sweden at time of self-employment entry

Fig. 22 Evolution of capital income among natives and European immigrants by length of stay in Sweden at time of self-employment entry, conditioning on positive capital income
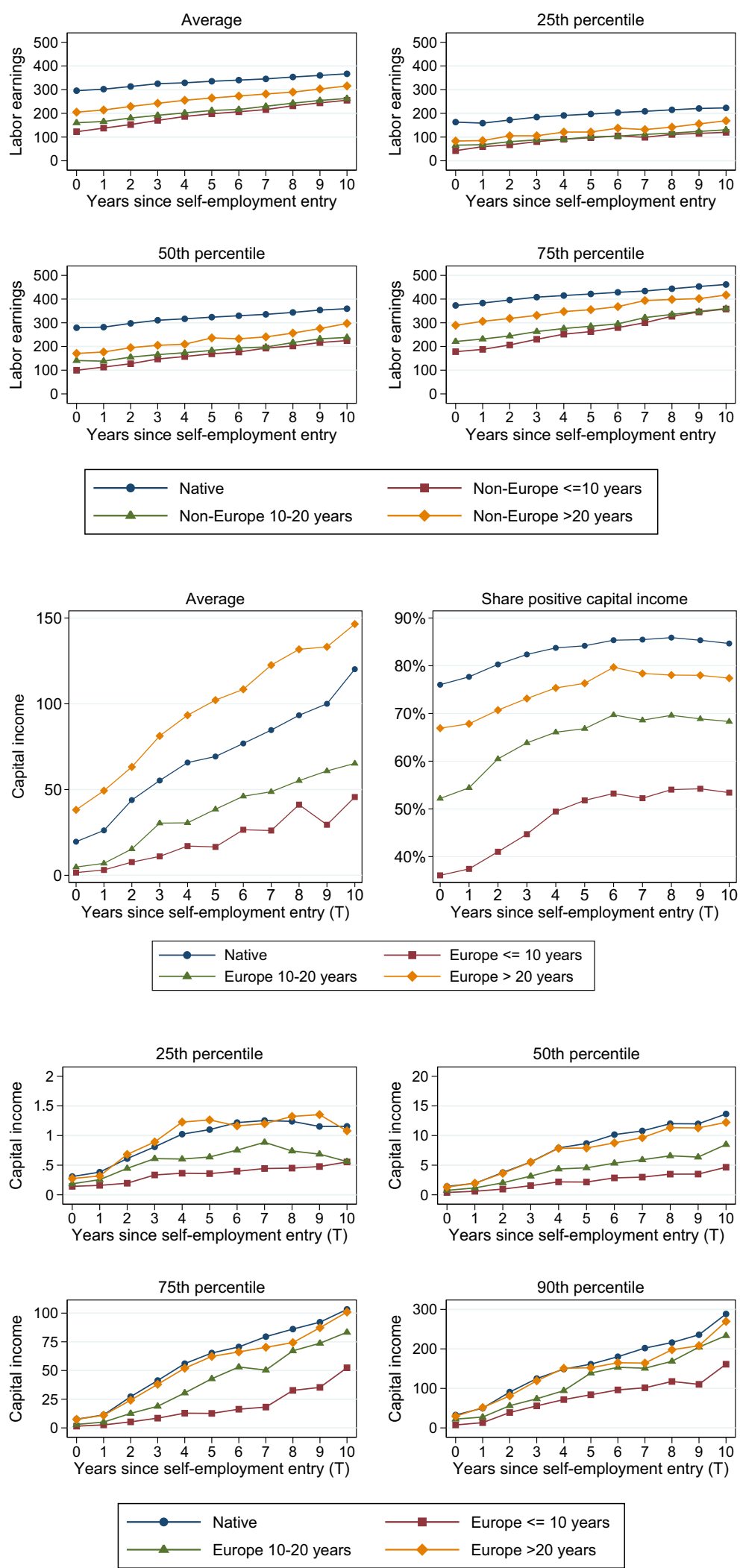
Fig. 23 Average capital income and share with positive capital income among natives and non-European immigrants by length of stay in Sweden at time of self-employment entry

Fig. 24 Evolution of capital income among natives and non-European immigrants by length of stay in Sweden at time of self-employment entry, conditioning on positive capital income

Fig. 25 Evolution of labor income among natives and European immigrants, by cohort
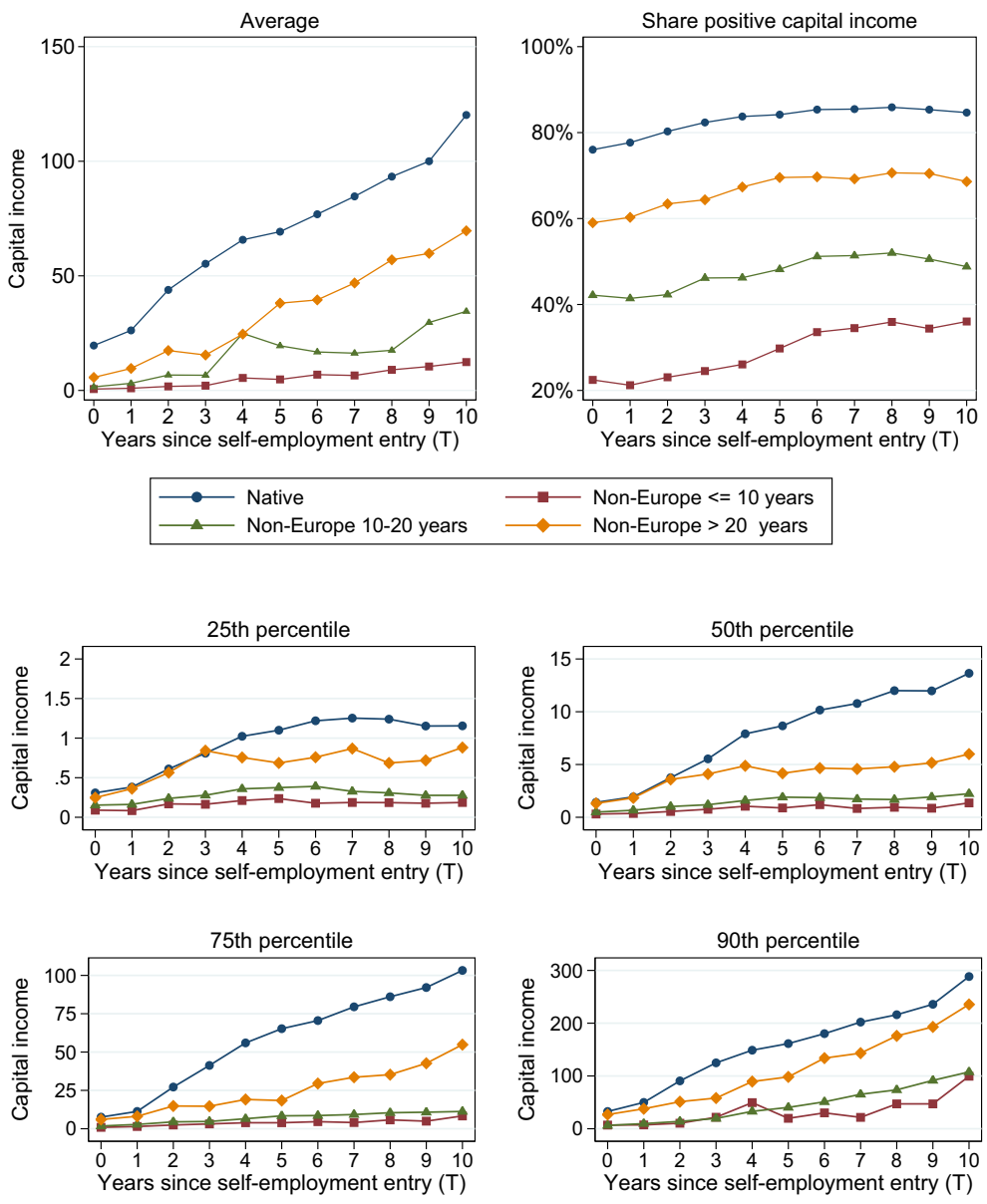

$\begin{array}{ll}\longrightarrow & \text { Native } \\ \text { Non-Europe } 10-20 \text { years } \quad \text { Non-Europe }<=10 \text { years } \\ \text { Non-Europe }>20 \text { years }\end{array}$
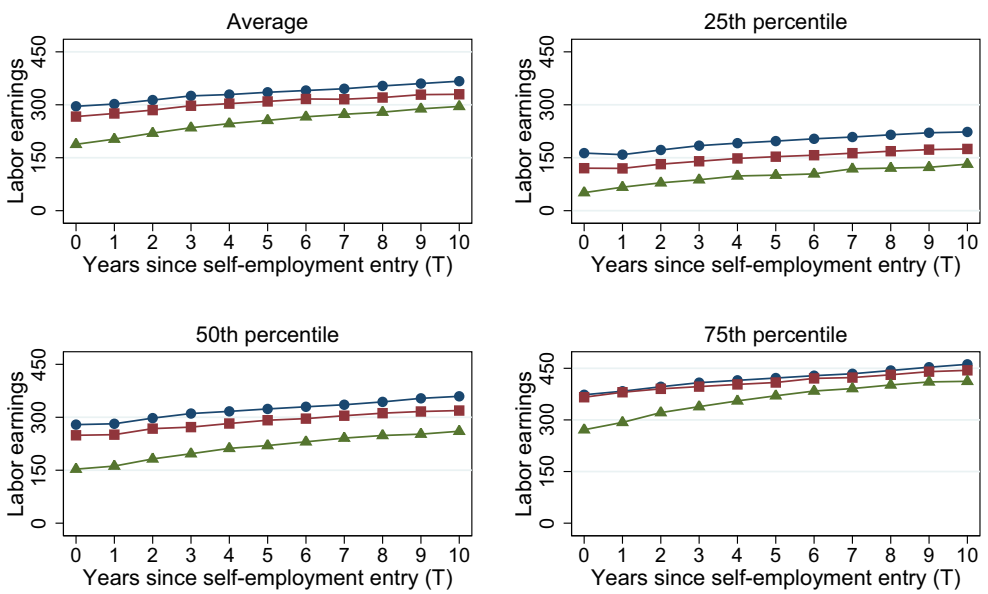

$\begin{array}{lll}\longrightarrow & \text { Native } \\ \longrightarrow & \text { European arrived after } 1990 & \text { European arrived before } 1990 \\ \longrightarrow & \end{array}$


Fig. 26 Average capital income and share with positive capital income among natives and European immigrants, by cohort

Fig. 27 Evolution of capital income among natives and European immigrants by cohort, conditioning on positive capital income

Fig. 28 The share of self-employed natives and European immigrants who have an incorporated business and work in an industry with low barriers to entry, by cohort
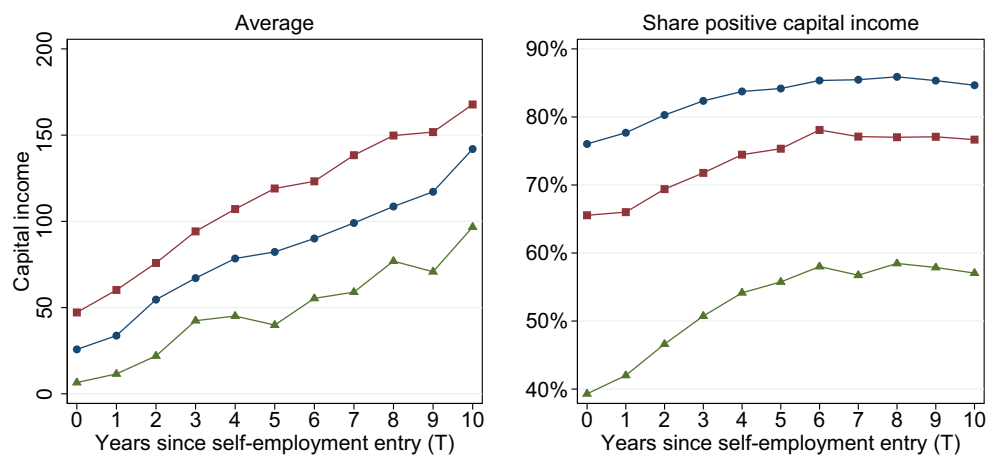

$\begin{array}{ll}\longrightarrow & \text { Native } \\ \longrightarrow & \text { European arrived after } 1990\end{array}$

ㄴ.? European arrived before 1990
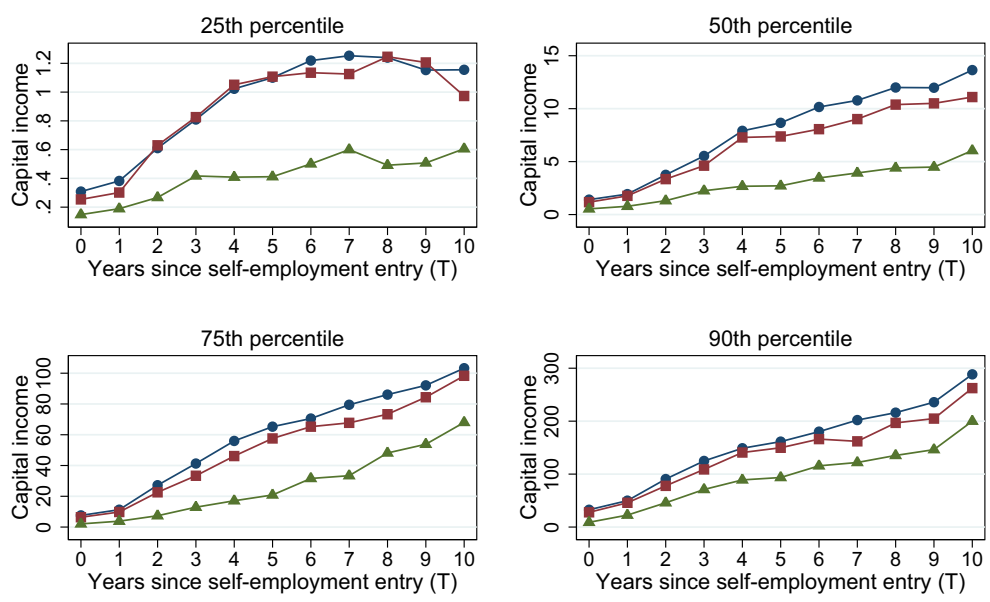

$\begin{array}{ll}\longrightarrow & \text { Native } \\ \longrightarrow & \text { European arrived after } 1990\end{array}$

European arrived before 1990
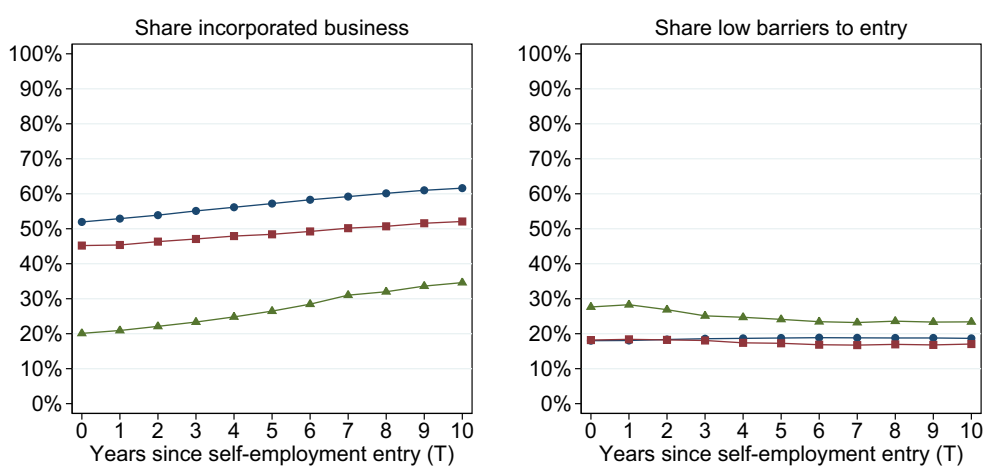

$\longrightarrow$ Native
$\longrightarrow \quad$ European arrived after 1990

$\longrightarrow$ European arrived before 1990 
Fig. 29 Evolution of labor income among natives and non-European immigrants, by cohort

Fig. 30 Average capital income and share with positive capital income among natives and non-European immigrants, by cohort

Fig. 31 Evolution of capital income among natives and non-European immigrants by cohort, conditioning on positive capital income
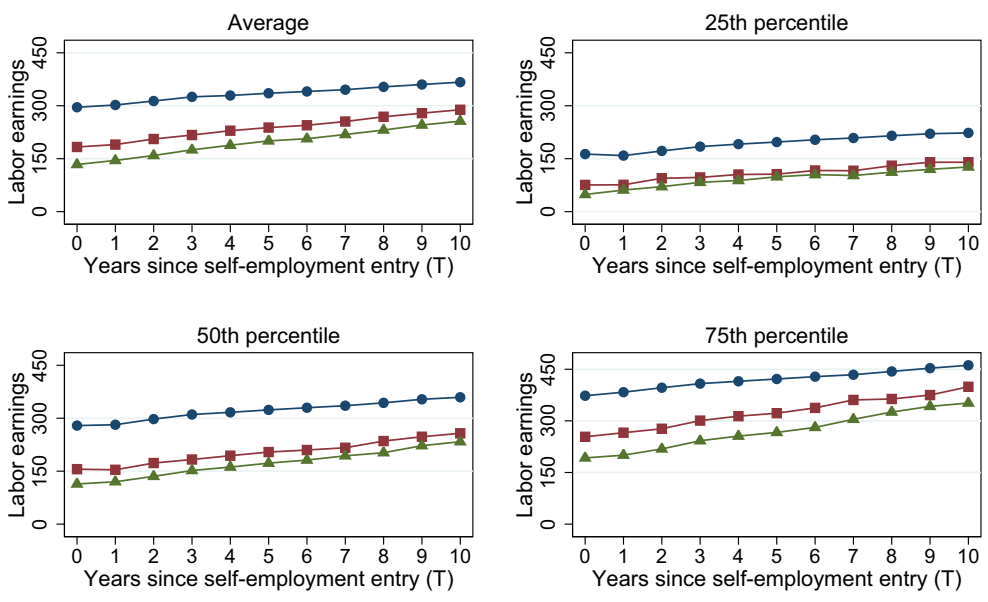

$\longrightarrow$ Native
$\longrightarrow \quad$ Non-European arrived after 1990

Non-European arrived before 1990
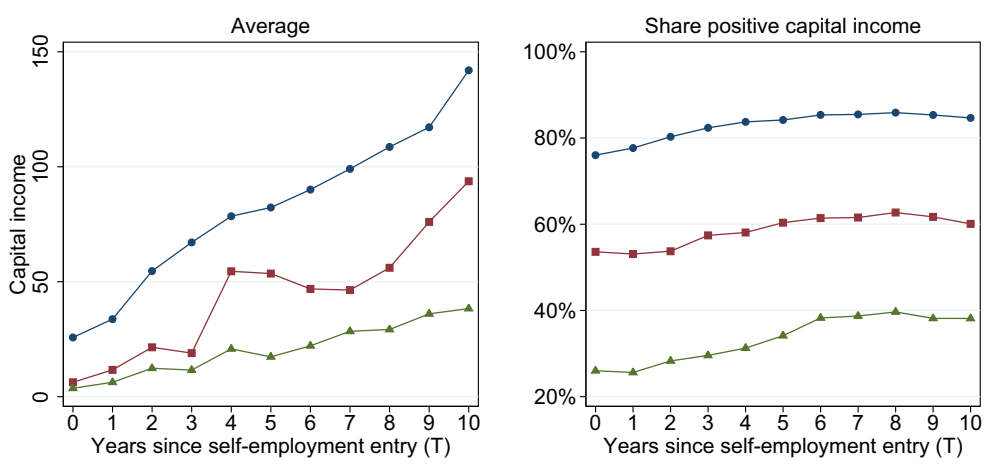

$\begin{array}{ll}\longrightarrow & \text { Native } \\ \longrightarrow & \text { Non-European arrived after } 1990\end{array}$

- Non-European arrived before 1990
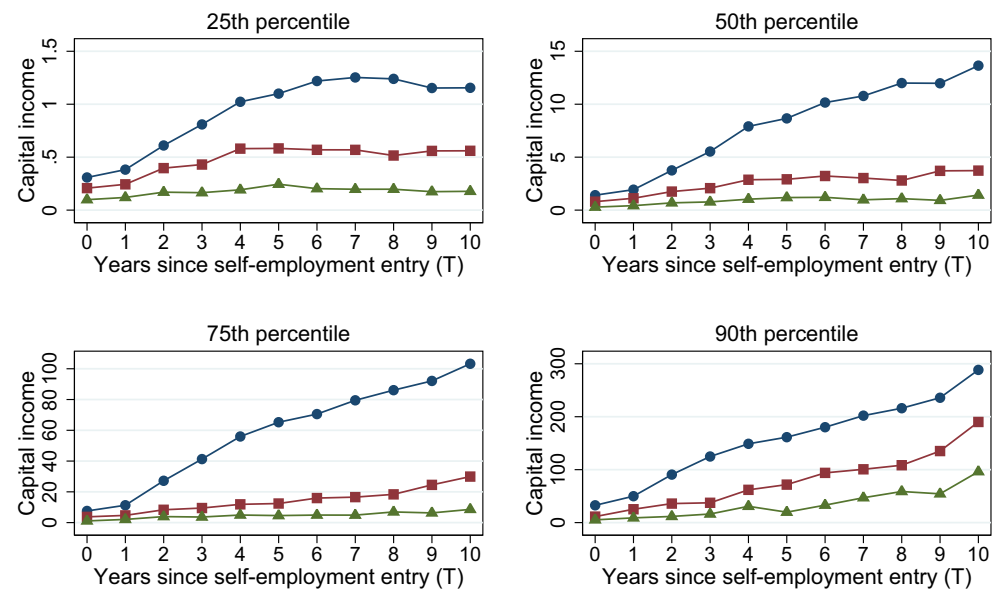

Non-European arrived before 1990 
Fig. 32 The share of self-employed natives and non-European immigrants who have an incorporated business and work in an industry with low barriers to entry, by cohort
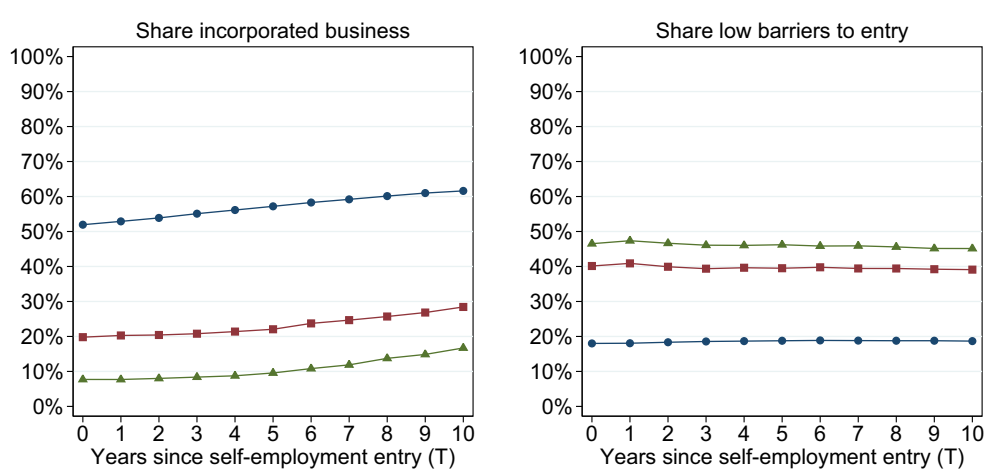

$\longrightarrow$ Native
$\longrightarrow$ Non-European arrived after 1990
$\longrightarrow$

\section{Appendix B: Appendix tables}

Table 10 Summary statistics for the register sample by corporate form

\begin{tabular}{|c|c|c|c|c|c|c|}
\hline & (1) & (2) & (3) & (4) & (5) & (6) \\
\hline & \multicolumn{3}{|c|}{ Incorporated firm owners } & \multicolumn{3}{|c|}{ Unincorporated firm owners } \\
\hline & Native & European & Non-European & Native & European & Non-European \\
\hline \multicolumn{7}{|c|}{ Outcome variables (averages in SEK): } \\
\hline Labor income & $\begin{array}{l}418000 \\
(209000)\end{array}$ & $\begin{array}{l}403000 \\
(194000)\end{array}$ & $\begin{array}{l}357000 \\
(181000)\end{array}$ & $\begin{array}{l}242000 \\
(170000)\end{array}$ & $\begin{array}{l}217000 \\
(163000)\end{array}$ & $\begin{array}{l}193000 \\
(121000)\end{array}$ \\
\hline Capital income & $\begin{array}{l}109000 \\
(355000)\end{array}$ & $\begin{array}{l}90300 \\
(234000)\end{array}$ & $\begin{array}{l}86200 \\
(301000)\end{array}$ & $\begin{array}{l}25500 \\
(898000)\end{array}$ & $\begin{array}{l}44100 \\
(1839000)\end{array}$ & $\begin{array}{l}5720 \\
(42300)\end{array}$ \\
\hline \multicolumn{7}{|c|}{ Characteristics at the year of self-employment entry: } \\
\hline Age & $\begin{array}{l}41.370 \\
(7.696)\end{array}$ & $\begin{array}{l}43.761 \\
(6.730)\end{array}$ & $\begin{array}{l}40.355 \\
(7.367)\end{array}$ & $\begin{array}{l}39.263 \\
(8.854)\end{array}$ & $\begin{array}{l}41.405 \\
(8.015)\end{array}$ & $\begin{array}{l}38.468 \\
(8.057)\end{array}$ \\
\hline Male & $\begin{array}{l}0.807 \\
(0.395)\end{array}$ & $\begin{array}{l}0.739 \\
(0.439)\end{array}$ & $\begin{array}{l}0.850 \\
(0.357)\end{array}$ & $\begin{array}{l}0.648 \\
(0.478)\end{array}$ & $\begin{array}{l}0.607 \\
(0.488)\end{array}$ & $\begin{array}{l}0.793 \\
(0.405)\end{array}$ \\
\hline Primary school & $\begin{array}{l}0.138 \\
(0.345)\end{array}$ & $\begin{array}{l}0.155 \\
(0.362)\end{array}$ & $\begin{array}{l}0.224 \\
(0.417)\end{array}$ & $\begin{array}{l}0.147 \\
(0.354)\end{array}$ & $\begin{array}{l}0.130 \\
(0.336)\end{array}$ & $\begin{array}{l}0.293 \\
(0.455)\end{array}$ \\
\hline High school & $\begin{array}{l}0.527 \\
(0.499)\end{array}$ & $\begin{array}{l}0.437 \\
(0.496)\end{array}$ & $\begin{array}{l}0.369 \\
(0.483)\end{array}$ & $\begin{array}{l}0.586 \\
(0.493)\end{array}$ & $\begin{array}{l}0.478 \\
(0.500)\end{array}$ & $\begin{array}{l}0.446 \\
(0.497)\end{array}$ \\
\hline College & $\begin{array}{l}0.335 \\
(0.472)\end{array}$ & $\begin{array}{l}0.408 \\
(0.492)\end{array}$ & $\begin{array}{l}0.407 \\
(0.492)\end{array}$ & $\begin{array}{l}0.268 \\
(0.443)\end{array}$ & $\begin{array}{l}0.393 \\
(0.488)\end{array}$ & $\begin{array}{l}0.260 \\
(0.439)\end{array}$ \\
\hline Marital status & $\begin{array}{l}0.535 \\
(0.499)\end{array}$ & $\begin{array}{l}0.646 \\
(0.478)\end{array}$ & $\begin{array}{l}0.714 \\
(0.452)\end{array}$ & $\begin{array}{l}0.403 \\
(0.490)\end{array}$ & $\begin{array}{l}0.572 \\
(0.495)\end{array}$ & $\begin{array}{l}0.707 \\
(0.455)\end{array}$ \\
\hline Children in household & $\begin{array}{l}1.120 \\
(1.092)\end{array}$ & $\begin{array}{l}1.109 \\
(1.078)\end{array}$ & $\begin{array}{l}1.364 \\
(1.212)\end{array}$ & $\begin{array}{l}0.892 \\
(1.068)\end{array}$ & $\begin{array}{l}0.910 \\
(1.062)\end{array}$ & $\begin{array}{l}1.440 \\
(1.279)\end{array}$ \\
\hline Low barrier industry & $\begin{array}{l}0.189 \\
(0.392)\end{array}$ & $\begin{array}{l}0.148 \\
(0.356)\end{array}$ & $\begin{array}{l}0.257 \\
(0.438)\end{array}$ & $\begin{array}{l}0.167 \\
(0.373)\end{array}$ & $\begin{array}{l}0.259 \\
(0.438)\end{array}$ & $\begin{array}{l}0.462 \\
(0.499)\end{array}$ \\
\hline$N$ & 28300 & 1422 & 420 & 26186 & 2667 & 2675 \\
\hline
\end{tabular}

Mean coefficients; Standard deviation in parentheses 
Table 11 Comparison of survey respondents and non-respondents

\begin{tabular}{|c|c|c|c|c|c|c|}
\hline & (1) & (2) & (3) & (4) & (5) & (6) \\
\hline & \multicolumn{3}{|c|}{ Respondents } & \multicolumn{3}{|c|}{ Non-respondents } \\
\hline & Native & European & Non-European & Native & European & Non-European \\
\hline \multirow[t]{2}{*}{ Age } & 56.9 & 57.8 & 54.1 & 54.0 & 54.4 & 51.4 \\
\hline & $(9.001)$ & $(8.641)$ & $(8.390)$ & $(9.607)$ & $(9.332)$ & $(8.953)$ \\
\hline \multirow[t]{2}{*}{ Female } & 0.521 & 0.524 & 0.279 & 0.481 & 0.484 & 0.269 \\
\hline & $(0.500)$ & $(0.500)$ & $(0.449)$ & $(0.500)$ & $(0.500)$ & $(0.443)$ \\
\hline \multirow[t]{2}{*}{ Primary school } & 0.151 & 0.155 & 0.170 & 0.191 & 0.216 & 0.277 \\
\hline & $(0.358)$ & $(0.362)$ & $(0.376)$ & $(0.393)$ & $(0.411)$ & $(0.448)$ \\
\hline \multirow[t]{2}{*}{ High school } & 0.515 & 0.422 & 0.434 & 0.574 & 0.484 & 0.450 \\
\hline & $(0.500)$ & $(0.494)$ & $(0.496)$ & $(0.495)$ & $(0.500)$ & $(0.498)$ \\
\hline \multirow[t]{2}{*}{ College } & 0.333 & 0.423 & 0.396 & 0.235 & 0.300 & 0.273 \\
\hline & $(0.472)$ & $(0.494)$ & $(0.489)$ & $(0.424)$ & $(0.458)$ & $(0.445)$ \\
\hline \multirow[t]{2}{*}{ Marital status } & 0.635 & 0.662 & 0.714 & 0.570 & 0.639 & 0.691 \\
\hline & $(0.482)$ & $(0.473)$ & $(0.452)$ & $(0.495)$ & $(0.480)$ & $(0.462)$ \\
\hline \multirow[t]{2}{*}{ Children in household } & 0.372 & 0.352 & 0.708 & 0.499 & 0.507 & 0.915 \\
\hline & $(0.763)$ & $(0.791)$ & $(1.036)$ & $(0.876)$ & $(0.909)$ & $(1.174)$ \\
\hline \multirow[t]{2}{*}{ Incorporated business } & 0.477 & 0.335 & 0.216 & 0.437 & 0.268 & 0.189 \\
\hline & $(0.500)$ & $(0.472)$ & $(0.412)$ & $(0.496)$ & $(0.443)$ & $(0.392)$ \\
\hline \multirow[t]{2}{*}{ Low barrier industry } & 0.244 & 0.235 & 0.450 & 0.271 & 0.276 & 0.445 \\
\hline & $(0.430)$ & $(0.424)$ & $(0.498)$ & $(0.444)$ & $(0.447)$ & $(0.497)$ \\
\hline \multirow[t]{2}{*}{ Average disposable income $\dagger$} & 333000 & 286000 & 243000 & 307000 & 254000 & 212000 \\
\hline & $(447000)$ & $(273000)$ & $(274000)$ & $(247000)$ & $(273000)$ & $(156000)$ \\
\hline$N$ & 2843 & 2418 & 1765 & 3157 & 3582 & 3742 \\
\hline
\end{tabular}

Mean coefficients; Standard deviations in parentheses. The summary statistics are computed from 2016 register data, which is the most recent year we could match with our survey data. The summary statistics for the respondents and non-respondents are unweighted. $\dagger$ Average disposable income between 2007-2016

Table 12 Earnings differences across the outcome distribution

$*$, ** and *** denote statistical significance at the 10,5 and 1 percent level, respectively. Robust standard error are shown in parenthesis. Control variables (age, gender, high school, college, marital status and number of children at household under age 18) are determined in the year of self-employment entry

\begin{tabular}{llll}
\hline & $(1)$ & $(2)$ & $(3)$ \\
& 25 th percentile & 50 th percentile & 75th percentile \\
\hline Dependent variable: Labor income & & \\
European & $-0.367 * * *$ & $-0.199 * * *$ & $-0.099 * * *$ \\
& $(0.020)$ & $(0.014)$ & $(0.011)$ \\
Non-European & $-0.675^{* * *}$ & $-0.552^{* * *}$ & $-0.396 * * *$ \\
& $(0.018)$ & $(0.014)$ & $(0.013)$ \\
$N$ & 61670 & 61670 & 61670 \\
Dependent variable: Capital & income & & $-0.521 * * *$ \\
European & $-1.334 * * *$ & $-0.899 * * *$ & $(0.052)$ \\
& $(0.084)$ & $(0.058)$ & $-1.958^{* * *}$ \\
Non-European & $-2.882^{* * *}$ & $-2.527 * * *$ & $(0.077)$ \\
& $(0.098)$ & $(0.095)$ & 58635 \\
\hline
\end{tabular}


Table 13 Extended regression table, main outcome differences

$*, * *$ and $* * *$ denote statistical significance at the 10,5 and 1 percent level, respectively.

Robust standard error are shown in parenthesis

Table 14 Earnings differences by education level

$*, * *$ and $* * *$ denote statistical significance at the 10,5 and 1 percent level, respectively.

Robust standard error are shown in parenthesis. Control variables (age, gender, marital status and number of children at household under age 18) are determined at the year of self-employment entry

\begin{tabular}{|c|c|c|c|c|}
\hline & (1) & (2) & (3) & (4) \\
\hline & Labor income & Labor income & Capital income & Capital income \\
\hline \multirow[t]{2}{*}{ European } & $-0.274 * * *$ & $-0.269 * * *$ & $-0.815^{* * *}$ & $-0.945 * * *$ \\
\hline & $(0.0161)$ & $(0.0157)$ & $(0.0497)$ & $(0.0490)$ \\
\hline \multirow[t]{2}{*}{ Non-European } & $-0.457 * * *$ & $-0.523 * * *$ & $-2.224 * * *$ & $-2.313 * * *$ \\
\hline & $(0.0144)$ & $(0.0144)$ & $(0.0621)$ & $(0.0625)$ \\
\hline \multirow[t]{2}{*}{ Age } & & $-0.00286 * * *$ & & $0.0311 * * *$ \\
\hline & & $(0.000414)$ & & $(0.00136)$ \\
\hline \multirow[t]{2}{*}{ Male } & & $0.408 * * *$ & & $0.963 * * *$ \\
\hline & & $(0.00789)$ & & $(0.0234)$ \\
\hline \multirow[t]{2}{*}{ High school } & & $0.0736 * * *$ & & $0.281 * * *$ \\
\hline & & $(0.00915)$ & & $(0.0332)$ \\
\hline \multirow[t]{2}{*}{ College } & & $0.317 * * *$ & & $1.353 * * *$ \\
\hline & & $(0.0101)$ & & $(0.0343)$ \\
\hline \multirow[t]{2}{*}{ Marital status } & & $0.0841 * * *$ & & $0.273 * * *$ \\
\hline & & $(0.00726)$ & & $(0.0242)$ \\
\hline \multirow[t]{2}{*}{ Children in household } & & $0.0685^{* * *}$ & & $0.107 * * *$ \\
\hline & & $(0.00308)$ & & $(0.0107)$ \\
\hline$N$ & 61670 & 61670 & 58635 & 58635 \\
\hline
\end{tabular}

\begin{tabular}{|c|c|c|c|c|}
\hline & (1) & (2) & (3) & (4) \\
\hline & Labor income & Labor income & Capital income & Capital income \\
\hline \multirow[t]{2}{*}{ European } & $-0.269 * * *$ & $-0.197 * * *$ & $-0.945^{* * *}$ & $-0.684 * * *$ \\
\hline & $(0.0157)$ & $(0.0412)$ & $(0.0490)$ & $(0.137)$ \\
\hline \multirow[t]{2}{*}{ Non-European } & $-0.523 * * *$ & $-0.482 * * *$ & $-2.313 * * *$ & $-2.219 * * *$ \\
\hline & $(0.0144)$ & $(0.0263)$ & $(0.0625)$ & $(0.128)$ \\
\hline \multirow[t]{2}{*}{ High school } & $0.0736 * * *$ & $0.0792 * * *$ & $0.281 * * *$ & $0.292 * * *$ \\
\hline & $(0.00915)$ & $(0.00971)$ & $(0.0332)$ & $(0.0348)$ \\
\hline \multirow[t]{2}{*}{ College } & $0.317 * * *$ & $0.334 * * *$ & $1.353 * * *$ & $1.402 * * *$ \\
\hline & $(0.0101)$ & $(0.0108)$ & $(0.0343)$ & $(0.0358)$ \\
\hline \multirow[t]{2}{*}{ European $\times$ High School } & & -0.0299 & & -0.131 \\
\hline & & $(0.0463)$ & & $(0.154)$ \\
\hline \multirow[t]{2}{*}{ European $\times$ College } & & $-0.148 * * *$ & & $-0.501 * * *$ \\
\hline & & $(0.0494)$ & & $(0.156)$ \\
\hline \multirow[t]{2}{*}{ Non-European $\times$ High School } & & -0.0324 & & 0.000185 \\
\hline & & $(0.0341)$ & & $(0.156)$ \\
\hline \multirow[t]{2}{*}{ Non-European $\times$ College } & & $-0.0916^{* *}$ & & $-0.307 *$ \\
\hline & & $(0.0380)$ & & $(0.172)$ \\
\hline Control variables & Yes & Yes & Yes & Yes \\
\hline$N$ & 61670 & 61670 & 58635 & 58635 \\
\hline
\end{tabular}


Table 15 Summary statistics for all individuals who entered self-employment between 2002-2006 (irrespective of the length of their self-employment spells)

\begin{tabular}{|c|c|c|c|c|c|}
\hline & $\begin{array}{l}(1) \\
\text { Native }\end{array}$ & $\begin{array}{l}\text { (2) } \\
\text { European }\end{array}$ & $\begin{array}{l}\text { (3) } \\
\text { Non-European }\end{array}$ & $\begin{array}{l}(4) \\
(1)-(2)\end{array}$ & $\begin{array}{l}(5) \\
(1)-(3)\end{array}$ \\
\hline \multicolumn{6}{|c|}{ Characteristics at the year of self-employment entry: } \\
\hline Age & $\begin{array}{l}39.6 \\
(8.589)\end{array}$ & $\begin{array}{l}41.3 \\
(8.074)\end{array}$ & $\begin{array}{l}37.6 \\
(8.325)\end{array}$ & $-1.7 * * *$ & $2.0 * * *$ \\
\hline Male & $\begin{array}{l}0.694 \\
(0.461)\end{array}$ & $\begin{array}{l}0.617 \\
(0.486)\end{array}$ & $\begin{array}{l}0.750 \\
(0.433)\end{array}$ & $0.077 * * *$ & $-0.056^{* * *}$ \\
\hline Primary School & $\begin{array}{l}0.129 \\
(0.335)\end{array}$ & $\begin{array}{l}0.140 \\
(0.347)\end{array}$ & $\begin{array}{l}0.279 \\
(0.449)\end{array}$ & $-0.011 * * *$ & $-0.15^{* * *}$ \\
\hline High School & $\begin{array}{l}0.534 \\
(0.499)\end{array}$ & $\begin{array}{l}0.456 \\
(0.498)\end{array}$ & $\begin{array}{l}0.436 \\
(0.496)\end{array}$ & $0.078 * * *$ & $0.098 * * *$ \\
\hline College & $\begin{array}{l}0.338 \\
(0.473)\end{array}$ & $\begin{array}{l}0.404 \\
(0.491)\end{array}$ & $\begin{array}{l}0.284 \\
(0.451)\end{array}$ & $-0.066^{* * *}$ & $0.054 * * *$ \\
\hline Marital status & $\begin{array}{l}0.454 \\
(0.498)\end{array}$ & $\begin{array}{l}0.566 \\
(0.496)\end{array}$ & $\begin{array}{l}0.668 \\
(0.471)\end{array}$ & $-0.112 * * *$ & $-0.214 * * *$ \\
\hline Children in household & $\begin{array}{l}0.99 \\
(1.093)\end{array}$ & $\begin{array}{l}0.99 \\
(1.098)\end{array}$ & $\begin{array}{l}1.40 \\
(1.337)\end{array}$ & 0.0 & $-0.41 * * *$ \\
\hline Incorporated business & $\begin{array}{l}0.476 \\
(0.499)\end{array}$ & $\begin{array}{l}0.326 \\
(0.469)\end{array}$ & $\begin{array}{l}0.139 \\
(0.346)\end{array}$ & $0.15 * * *$ & $0.337 * * *$ \\
\hline Low barrier industry & $\begin{array}{l}0.170 \\
(0.376)\end{array}$ & $\begin{array}{l}0.210 \\
(0.407)\end{array}$ & $\begin{array}{l}0.387 \\
(0.487)\end{array}$ & $-0.04 * * *$ & $-0.217 * * *$ \\
\hline$N$ & 141268 & 11463 & 11499 & & \\
\hline
\end{tabular}

The table contains averages with standard deviations in parentheses. *** and *** denote statistical significance at the 10,5 , and 1 percent level, respectively. Columns (4) and (5) refer to pair-wise $t$-tests for testing statistically significant differences. Self-employment in the agricultural sector is excluded

Table 16 Immigrant-native logarithmic earnings differences, panel data approach

\begin{tabular}{|c|c|c|c|c|}
\hline & (1) & (2) & (3) & (4) \\
\hline & \multicolumn{2}{|l|}{ OLS estimation } & \multicolumn{2}{|c|}{ Random effects model } \\
\hline & Labor income & Capital income & Labor income & Capital income \\
\hline \multirow[t]{2}{*}{ European } & $-0.239 * * *$ & $-0.564 * * *$ & $-0.253 * * *$ & $-0.668 * * *$ \\
\hline & $(0.0125)$ & $(0.0398)$ & $(0.0143)$ & $(0.0394)$ \\
\hline \multirow[t]{2}{*}{ Non-European } & $-0.560 * * *$ & $-1.424 * * *$ & $-0.523 * * *$ & $-1.516^{* * *}$ \\
\hline & $(0.0129)$ & $(0.0529)$ & $(0.0137)$ & $(0.0482)$ \\
\hline Control variables & Yes & Yes & Yes & Yes \\
\hline Year dummies & Yes & Yes & Yes & Yes \\
\hline County dummies & Yes & Yes & Yes & Yes \\
\hline County $\times$ year dummies & Yes & Yes & Yes & Yes \\
\hline$N$ & 719260 & 594527 & 719260 & 594527 \\
\hline
\end{tabular}

$*, * *$ and $* * *$ denote statistical significance at the 10,5 and 1 percent level, respectively. Robust standard error are shown in parenthesis. The control variables include age, gender, high school, college, marital status and number of children at household under age 18 . We further control for year and region (at county level) as well as region-year time trends. Due to the logarithmic outcome variable, self-employed individuals with zero labor or capital income are excluded in the regression 
Table 17 List of register variables

\begin{tabular}{|c|c|}
\hline Variable & Description \\
\hline Labor income & $\begin{array}{l}\text { Continuous variable: Taxable labor income from the tax administration measured in thou- } \\
\text { sands of SEK ( } 2016 \text { price level). Represents the sum of wage income, business income net } \\
\text { of employment-related tax deductions. }\end{array}$ \\
\hline Capital income & $\begin{array}{l}\text { Continuous variable: Total taxable interest and dividend income from the tax administration } \\
\text { measured in thousands of SEK ( } 2016 \text { price level). }\end{array}$ \\
\hline Disposable income & $\begin{array}{l}\text { Continuous variable: Sum of employment, business/capital income, social transfers, net of } \\
\text { taxes. From the tax administration, measured in thousands of SEK ( } 2016 \text { price level). }\end{array}$ \\
\hline Native & Dummy equal to one if born in Sweden and zero otherwise. \\
\hline European & Dummy equal to one if born in a European country, otherwise zero. \\
\hline Non-European & Dummy variable: 1 if born in non-European countries, otherwise zero. \\
\hline Age & Age in years \\
\hline Male & Dummy variable equal to one if male, otherwise zero. \\
\hline Marital status & Dummy variable equal to one if married, otherwise zero. \\
\hline Primary school & Dummy variable equal to one if nine years of compulsory schooling or less, otherwise zero. \\
\hline High school & Dummy variable equal to one if attended upper secondary school, otherwise zero. \\
\hline College & Dummy variable equal to one if university educated, otherwise zero. \\
\hline Children in household & Continuous variable: The number of children in the household under age 18 . \\
\hline Incorporated business & Dummy variable equal to one if owner of an incorporated firm, otherwise zero. \\
\hline Low barriers to entry & $\begin{array}{l}\text { Dummy variable equal to one if the industries associated with the self-employment spell } \\
\text { belong to personal service (excluding professional business service), transportation or retail } \\
\text { trade, otherwise zero. }\end{array}$ \\
\hline
\end{tabular}

Table 18 List of survey variables

\begin{tabular}{|c|c|}
\hline Variable & Description \\
\hline \multicolumn{2}{|l|}{ Background characteristics } \\
\hline Age at first business & $\begin{array}{l}\text { Continuous variable: Age at the first business experience. Equals the year } \\
\text { of first business minus the year of birth. (Question 6) }\end{array}$ \\
\hline Parents self-employed & $\begin{array}{l}\text { Dummy variable equal to one if parents are self-employed, zero otherwise. } \\
\text { (Question 7) }\end{array}$ \\
\hline Having family and relatives work in the business & $\begin{array}{l}\text { Dummy variable equal to one if wife/husband, partner, children, parents or } \\
\text { other relatives are working in the business, zero otherwise. (Question 8) }\end{array}$ \\
\hline Foreign-born employees & $\begin{array}{l}\text { Dummy variable equal to one if about half, more than half, or all of the } \\
\text { employees are born outside Sweden, zero otherwise. (Question 9) }\end{array}$ \\
\hline Foreign-born business suppliers & $\begin{array}{l}\text { Dummy variable equal to one if about half, more than half, or all suppliers } \\
\text { are born outside Sweden, zero otherwise. (Question 10) }\end{array}$ \\
\hline Foreign-born customers & $\begin{array}{l}\text { Dummy variable equal to one if half, more than half, or all customers are } \\
\text { born outside Sweden, zero otherwise. (Question 12) }\end{array}$ \\
\hline Personal relationship with customers & $\begin{array}{l}\text { Dummy variable equal to one if the respondent knows about half, more than } \\
\text { half, or all of his/her customers personally. (Question 13) }\end{array}$ \\
\hline High proficiency in Swedish & $\begin{array}{l}\text { Dummy variable equal to one if the person considers himself/herself to have } \\
\text { a high proficiency in Swedish. (Question 14) }\end{array}$ \\
\hline High proficiency in English & $\begin{array}{l}\text { Dummy variable equal to one if the person considers himself/herself to have } \\
\text { a high proficiency in English. (Question 15) }\end{array}$ \\
\hline Hours of work & $\begin{array}{l}\text { Categorical variable indicating whether working hours is below } 20,20-30 \text {, } \\
31-40,40-50,50-60,60-70 \text {, or above } 70 \text { hours. We code these categories as } \\
15,25,35,45,55,65 \text { and } 75 \text { hours. (Question } 16 \text { ) }\end{array}$ \\
\hline
\end{tabular}


Table 18 (continued)

Variable Description

Working as an employee in another job

Hours of work in other jobs

Wife/husband working hours in respondent's business

Enjoy being self-employed

Prefer to be employee

Luck most important for economic success

Achieved goals

Self-employed in next 5 years (yes/no)

Factors affecting self-employment

How important are the following people for your business? (Question 19)

Partner

Dummy variable equal to one if the respondent perceives that his/her partner (wife/husband) is fairly important or very important for the business, zero otherwise.

Children

Dummy variable equal to one if the respondent perceives that her/his children are fairly important or very important for the business, zero otherwise.

Relatives
Dummy variable equal to one if the person is working in another job as an employee, zero otherwise. (Question 17a)

Categorical variable indicating whether working hours is below 20, 20-30, $31-40,40-50,50-60,60-70$, or above 70 hours. We code these categories as $15,25,35,45,55,65$ and 75 hours. (Question 17b)

Categorical variable indicating whether working hours is below 20, 20-30, $31-40,40-50,50-60,60-70$, or above 70 hours. We code these categories as $15,25,35,45,55,65$ and 75 hours. (Question 18)

Dummy variable equal to one if the respondent strongly agrees or fully agrees that self-employment is enjoyable, zero otherwise. (Question 24a)

Dummy variable equal to one if the respondent strongly agrees or fully agrees that they would prefer to be wage employee, zero otherwise. (Question 24b)

Dummy variable equal to one if the person scores 4 or 5 on a five point scale, zero otherwise. Here 5 means that luck is most important for economic success and 1 means that hard work is most important for economic success. (Question 25)

Dummy variable equal to one if the person considers that he/she has achieved his/her goals as a business owner, zero otherwise. (Question 26)

Dummy variable equal to one if the person thinks that he/she will be selfemployed in 5 years, zero otherwise. (Question 27) important or very important for the business, zero otherwise.

How important are the following people in contributing your business? (Question 20)

Past employers

Past colleagues

Past classmates

Previous business partners

Neighbors and friends

How important has the following been for your success in self-employment? (Question 21)

Education in Sweden

Education in home-country

Work experience in Sweden

Work experience in home-country important or very important for the business, zero otherwise.

Dummy variable equal to one if the respondent perceives that past employers are fairly important or very important for the business, zero otherwise.

Dummy variable equal to one if the respondent perceives that past colleagues are fairly important or very important for the business, zero otherwise.

Dummy variable equal to one if the respondent perceives that past classmates are fairly important or very important for the business, zero otherwise.

Dummy variable equal to one if the respondent perceives that previous business partners are fairly important or very important for the business, zero otherwise.

Dummy variable equal to one if the respondent perceives that neighbors and friends are fairly

Dummy variable equal to one if the respondent perceives that having been educated in Sweden is fairly or very important for the business, zero otherwise.

Dummy variable equal to one if the respondent perceives that having been educated in his/her home-country is fairly important or very important for the business, zero otherwise.

Dummy variable equal to one if the respondent perceives that having previous Swedish job experience is fairly important or very important for the business, zero otherwise.

Dummy variable equal to one if the respondent perceives that having previous job experience from his/her home-country is fairly important or very important for the business, 0 otherwise. 
Table 18 (continued)

Variable Description

How important are the following factors in contributing the access of capital for your

businesses? (Question 23)

Bank loan

Inheritance

Gift from relatives

Borrowing from relatives

Gift from friends

Borrowing from friends

Salaries from other jobs

State subsidy

Other sources
Dummy variable equal to one if the respondent considers that bank loans are fairly important or very important for the financing of their busienss, zero otherwise.

Dummy variable equal to one if the respondent considers inheritance to be fairly important or very important for the financing of their business, zero otherwise.

Dummy variable equal to one if the respondent considers gifts from relatives to be fairly important or very important for the financing of their business, zero otherwise.

Dummy variable equal to one if the respondent considers borrowing from relatives to be fairly important or very important for the financing of their business, zero otherwise.

Dummy variable equal to one if the respondent considers gifts from friends to be fairly important or very important ifor the financing of their business, zero otherwise.

Dummy variable equal to one if the respondent considers borrowing from friends to be fairly important or very important for the financing of their business, zero otherwise.

Dummy variable equal to one if the respondent considers salaries from other jobs to be fairly important or very important for the financing of their business, zero otherwise.

Dummy variable equal to one if the respondent considers state subsidies to be fairly important or very important for the financing of their business, zero otherwise.

Dummy variable equal to one if the respondent considers other financial sources, such as risk capital, to be fairly important or very important for the financing of their business, zero otherwise.

Obstacles facing the long-term self-employed

How large of a concern are the following factors in affecting your business? (Question 22)

Bureaucracy

High taxes

High salaries

Access to capital

Tax complexity

Finding employees

Reaching customers

Suppliers

Crime
Dummy variable equal to one if the respondent considers bureaucracy to be a large problem or a very large problem for the business, zero otherwise.

Dummy variable equal to one if the respondent considers high taxes to be a large problem or very large problem for the business, zero otherwise.

Dummy variable equal to one if the respondent considers high salaries to be a large problem or a very large problem for the business, zero otherwise.

Dummy variable equal to one if the respondent considers the access to capital to be a large problem or a very large problem for the business, zero otherwise.

Dummy variable equal to one if the respondent thinks that understanding the tax system is a large problem or very large problem for the business, zero otherwise.

Dummy variable equal to one if the respondent thinks that finding employees is a large problem or a very large problem for the business, zero otherwise.

Dummy variable equal to one if the respondent thinks that reaching customers is a large problem or very large problem for the business, zero otherwise.

Dummy variable equal to one if the respondent thinks that suppliers of goods and services is a large problem or very large problem for running the business, zero otherwise.

Dummy variable equal to one if the respondent thinks that criminal activity is a large problem or very large problem for the business, zero otherwise. 
Open Access This article is licensed under a Creative Commons Attribution 4.0 International License, which permits use, sharing, adaptation, distribution and reproduction in any medium or format, as long as you give appropriate credit to the original author(s) and the source, provide a link to the Creative Commons licence, and indicate if changes were made. The images or other third party material in this article are included in the article's Creative Commons licence, unless indicated otherwise in a credit line to the material. If material is not included in the article's Creative Commons licence and your intended use is not permitted by statutory regulation or exceeds the permitted use, you will need to obtain permission directly from the copyright holder. To view a copy of this licence, visit http:// creativecommonshorg/licenses/by/4.0/.

\section{References}

Aldén, L., \& Hammarstedt, M. (2016). Discrimination in the credit market? Access to financial capital among selfemployed immigrants. Kyklos, 69(1), 3-31. https://doi.org/ 10.1111/kykl.12101.

Aldén, L., \& Hammarstedt, M. (2017). Egenföretagande bland utrikes födda: En översikt av utvecklingen under 2000talet. Arbetsmarknadsekonomiska rå,det - Underlagsrapport, $1 / 2017$.

Alstadsæter, A., \& Jacob, M. (2016). Dividend taxes and income shifting. The Scandinavian Journal of Economics, 118(4), 693-717. https://doi.org/10.1111/sjoe.12148.

Andersson, L., \& Hammarstedt, M. (2010). Intergenerational transmissions in immigrant self-employment: Evidence from three generations. Small Business Economics, 34(3), 261-276. https://doi.org/10.1007/s11187-008-9117-y.

Andersson, L., \& Hammarstedt, M. (2015). Ethnic enclaves, networks and self-employment among Middle Eastern immigrants in Sweden. International Migration, 53(6), 2740. https://doi.org/10.1111/j.1468-2435.2011.00714.x.

Asiedu, E., Freeman, J. A., \& Nti-Addae, A. (2012). Access to credit by small businesses: How relevant are race, ethnicity, and gender?. American Economic Review, 102(3), 53237. https://www.aeaweb.org/articles?id=10.1257/aer.102.3. 532.

Åslund, O., Hensvik, L., \& Skans, O.N. (2014). Seeking similarity: How immigrants and natives manage in the labor market. Journal of Labor Economics, 32(3), 405-441. https://doi.org/10.1086/674985.

Bastani, S., Giebe, T., \& Miao, C. (2020). Ethnicity and tax filing behavior. Journal of Urban Economics, 103215, 116. https://doi.org/10.1016/j.jue.2019.103215.

Blanchard, L., Zhao, B., \& Yinger, J. (2008). Do lenders discriminate against minority and woman entrepreneurs? Journal of Urban Economics, 63(2), 467-497. https://doi.org/10.1016/ j.jue.2007.03.001.

Blanchflower, D. G., \& Oswald, A. J. (1998). What makes an entrepreneur?. Journal of Labor Economics, 16(1), 26-60. https://doi.org/10.1086/209881.

Boguslaw, J. (2012). Svensk invandringspolitik under 500 år: 1512-2012. Studentlitteratur.
Borjas, G. J. (1986). The self-employment experience of immigrants. Journal of Human Resources, 21(4), 487-506. https://doi.org/10.2307/145764.

Clark, K., \& Drinkwater, S. (2000). Pushed out or pulled in? Self-employment among ethnic minorities in England and Wales. Labour Economics, 7(5), 603-628. https://doi.org/10.1016/S0927-5371(00)00015-4.

Clark, K., \& Drinkwater, S. (2002). Enclaves, neighbourhood effects and employment outcomes: Ethnic minorities in England and Wales. Journal of Population Economics, 15(1), 5-29. https://doi.org/10.1007/PL00003839.

Clark, K., Drinkwater, S., \& Robinson, C. (2017). Selfemployment amongst migrant groups: New evidence from England and Wales. Small Business Economics, 48(4), 1047-1069. https://doi.org/10.1007/s11187-016-9804-z.

Constant, A., \& Zimmermann, K. F. (2006). The making of entrepreneurs in germany: Are native men and immigrants alike? Small Business Economics, 26(3), 279-300. https://doi.org/10.1007/s11187-005-3004-6.

Da Rin, M., Di Giacomo, M., \& Sembenelli, A. (2011). Entrepreneurship, firm entry, and the taxation of corporate income: Evidence from Europe. Journal of Public Economics, 95(9-10), 1048-1066. https://doi.org/10.1016/ j.jpubeco.2010.06.010.

DeTienne, D. R. (2010). Entrepreneurial exit as a critical component of the entrepreneurial process: Theoretical development. Journal of Business Venturing, 25(2), 203-215. https://doi.org/10.1016/j.jbusvent.2008.05.004.

Edmark, K., \& Gordon, R. H. (2013). The choice of organizational form by closely-held firms in Sweden: Tax versus non-tax determinants. Industrial and Corporate Change, 22(1), 219-243. https://doi.org/10.1093/icc/dts045.

Ek, S., Hammarstedt, M., \& Skedinger, P. (2020). Enkla jobb och kunskaper i svenska - Nycklar till integration? SNSförlag.

Fairlie, R. W. (1999). The absence of the African-American owned business: An analysis of the dynamics of selfemployment. Journal of Labor Economics, 17(1), 80-108. https://doi.org/10.1086/209914.

Fairlie, R. W., \& Meyer, B. D. (1996). Ethnic and racial selfemployment differences and possible explanations. Journal of Human Resources, 31(4), 757-793. https://doi.org/10. 2307/146146.

Fairlie, R. W., \& Robb, A. M. (2007a). Families, human capital, and small business: Evidence from the characteristics of business owners survey. ILR Review, 60(2), 225-245. https://doi.org/10.1177/001979390706000204.

Fairlie, R. W., \& Robb, A. M. (2007b). Why are black-owned businesses less successful than white-owned businesses? The role of families, inheritances, and business human capital. Journal of Labor Economics, 25(2), 289-323. https://doi.org/10.1086/510763.

Giuliano, L., Levine, D. I., \& Leonard, J. (2009). Manager race and the race of new hires. Journal of Labor Economics, 27(4), 589-631. https://doi.org/10.1086/605946.

Hammarstedt, M. (2001). Immigrant self-employment in Sweden-its variation and some possible determinants. Entrepreneurship \& Regional Development, 13(2), 147161. https://doi.org/10.1080/08985620010004106.

Hammarstedt, M., \& Miao, C. (2020). Self-employed immigrants and their employees: Evidence from Swedish 
employer-employee data. Review of Economics of the Household, 18(1), 35-68. https://doi.org/10.1007/s11150019-09446-1.

Hammarstedt, M., \& Shukur, G. (2009). Testing the homecountry self-employment hypothesis on immigrants in Sweden. Applied Economics Letters, 16(7), 745-748. https://doi.org/10.1080/13504850701221907.

Hout, M., \& Rosen, H. (2000). Self-employment, family background, and race. Journal of Human Resources, 35(4), 670-692. https://doi.org/10.2307/146367.

Kerr, W. R., \& Mandorff, M. (2015). Social networks, ethnicity and entrepreneurship. Technical report, National Bureau of Economic Research.

Le, A. T. (2000). The determinants of immigrant selfemployment in Australia. International Migration Review, 34(1), 183-214. https://doi.org/10.2307/2676017.

Levine, R., \& Rubinstein, Y. (2017). Smart and illicit: Who becomes an entrepreneur and do they earn more?
The Quarterly Journal of Economics, 132(2), 963-1018. https://doi.org/10.1093/qje/qjw044.

Lofstrom, M., \& Bates, T. (2013). African Americans' pursuit of self-employment. Small Business Economics, 40(1), 7386. https://doi.org/10.1007/s11187-011-9347-2.

OECD (2017). Immigrants' self-employment and entrepreneurship activities.

Robb, A. M., \& Fairlie, R. W. (2009). Determinants of business success: An examination of Asian-owned businesses in the USA. Journal of Population Economics, 22(4), 827-858. https://doi.org/10.1007/s00148-008-0193-8.

Yuengert, A. M. (1995). Testing hypotheses of immigrant selfemployment. Journal of Human Resources, 30(1), 194-204. https://doi.org/10.2307/146196.

Publisher's note Springer Nature remains neutral with regard to jurisdictional claims in published maps and institutional affiliations. 